\title{
Weichselian stratigraphy, geomorphology and glacial dynamics in southern Finnish Lapland
}

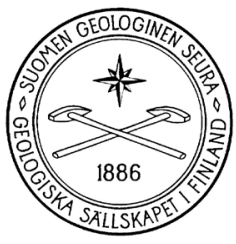

\author{
Pertti Sarala \\ Geological Survey of Finland, P.O. Box 77, FI-96101 Rovaniemi, Finland
}

\begin{abstract}
Quaternary stratigraphy and geomorphology were investigated by using aerial photo interpretation, digital elevation models and stratigraphical studies in southern Finnish Lapland. The development of glacial morphology was examined by reconstructing glacial flow patterns and subglacial conditions with emphasis on glacial dynamics. By comparing the climate history and available chronological data the ice-sheet development during the Weichselian was modelled in the area. Also, the Quaternary lithostratigraphy with descriptions, formal names and type sections of the Peräpohja Group was proposed.

Glacial morphology with clear indication of glacial flow directions represents two Weichselian glacial advances in the area of southern Finnish Lapland. The older, northwest-southeast oriented glacial movement was seen as a drumlin field and was preserved under a later cold-based ice sheet. A west-east oriented landform assemblage of ribbed moraines, drumlins and flutings mainly indicated the younger glacial phase. Of the age of ice sheet development during the Weichselian two alternative interpretations have been presented: In the first model, the first glacial advance occurred during the Early Weichselian and was followed by interstadial about 85-74 ka ago. The Middle and Late Weichselian glaciation was continuously covering southern Finnish Lapland after that. The second model includes a new interpretation, in which the first glacial advance that reached the area is connected to the beginning of the Middle Weichselian. Ice-free interstadial occurred about 50-30 ka ago before the Late Weichselian glacial advance, when the Weichselian maximum was reached.
\end{abstract}

Key words: glacial geology, geomorphology, moraines, ribbed moraines, drumlins, till, stratigraphy, glaciation, Pleistocene, Weichselian, Lapland Province, Finland

e-mail: pertti.sarala@gtk.fi 


\section{Introduction}

The area of Peräpohjola, in southern Finnish Lapland is situated in the centre of areas glaciated during the Weichselian age (Fig. 1). Core areas of the Fennoscandian glaciers repeatedly existed in the Norwegian and Swedish mountain area. In the eastern sector, the ice margin proceeded as far as the northwest Russian Plain during the Late Weichselian Maximum (LGM, 25-9 ka). Before that, several glacial phases were developed during the Early (117-75 ka) and Middle (75-25 ka) Weichselian, but not in such a large volume (cf. Svendsen et al., 2004). At the same time, large ice sheets with variable dimensions also existed in northern Russia and North America.

Glaciated areas can be distinguished studying the geomorphology composed of depositional and ero- sional formations during several glaciations. Subglacial conditions with glacial dynamics are factors that have an influence on active ice, subglacial bedform generation and the preservation of earlier morphology (e.g. Bouchard, 1989; Menzies \& Shilts, 1996; Clark, 1999; Evans \& Rea, 1999; Hart, 1999). In suitable subglacial conditions, for example under active ice lobes, the landform associations of drumlins, flutings and ribbed moraines can be developed (e.g. Aario, 1977a; Lundqvist, 1969, 1989). Instead, when the ice sheet has its' largest extent, the core area remains cold-based, which helps preserve older glacial morphology (Kleman, 1994; Kleman \& Borgström, 1996). In many research papers (e.g. Kurimo, 1974, 1982; Sutinen, 1992; Kleman \& Borgström, 1996; Clark, 1997; Hättestrand, 1997; Punkari, 1997; Boulton et al., 2001; Kleman et al., 2001), glacial

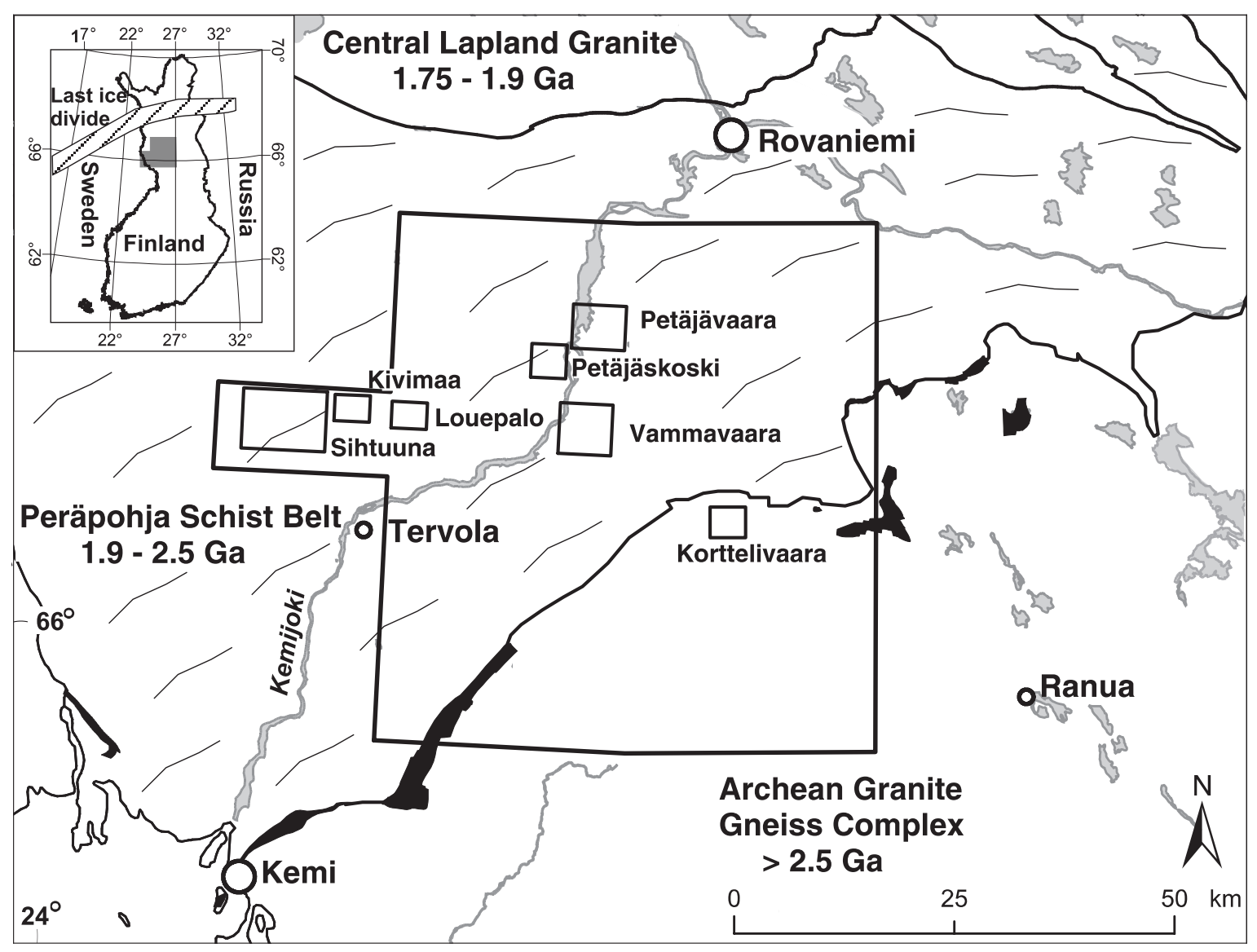

Fig. I. The study area location and the test sites together with a generalized bedrock map of the Peräpohja Schist Belt in southern Finnish Lapland. Layered intrusions $2.44 \mathrm{Ga}$ are marked as black areas. Modified after Perttunen et al. (1997). Topographic features (C) National Land Survey of Finland, permission number 54/LA/05. 
landforms and their relation to certain depositional conditions were used to reconstruct ice sheets dynamics in the Northern Hemisphere.

Glacial flow patterns based on till fabrics and striae, together with till stratigraphy were used to reconstruct ice sheet development during the former glaciations. By correlating microfossil spectra of the inter-till layers the glacial chronology was created. The works of Kujansuu (1967), Aario \& Forsström (1979), Hirvas (1991) and Nenonen (1995) are good examples of regional glacial geological investigations in Finland. Aario (1977a, 1990) has also put forward a classification of glacial landforms and their associations in northern Finland. But, a lack of reliable dating methods for interglacial or interstadial deposits has been problematic when studying earlier Weichselian stages. In Finland, dating is mainly based on radiocarbon dates and climate indications from microfossil content (cf. Hirvas \& Nenonen, 1987; Hirvas, 1991; Nenonen, 1995; Saarnisto \& Salonen, 1995), although the use of radiocarbon dating is limited to organic material younger than $45-50 \mathrm{ka}$. When suitable clastic, sorted sediments occur, thermoluminescence (TL) and optically stimulated luminescence (OSL) methods are useful for dating. These methods have also been used in Finland but concentrated mainly in southern and central areas (cf. Jungner, 1987; Niemelä \& Jugner, 1991; Hütt et al., 1993; Nenonen, 1995). Some radiocarbon (Korpela, 1969; Kujansuu, 1975; Siivonen, 1975; Mäkinen, 1979; Hirvas, 1991; Sutinen 1992) or TL and OSL (Punning \& Raukas, 1983; Hütt et al., 1984; Mäkinen, 1999) dates have also been published from the southern Finnish Lapland area.

The first investigations of Quaternary geology dated back to the beginning of the 1900's in northern Finland. For example, the works by Rosberg (1908) and Tanner $(1915,1930)$ were pioneer studies of geomorphology and stratigraphy in the area, describing different till units and esker systems. Tanner (1938) was also the first suggesting an ice-free stage during the Weichselian glaciation.

During the 1950's and 1960's, several studies on till stratigraphy were carried out in northern Finn- ish Lapland (e.g. Penttilä, 1963; Kujansuu, 1967). Deep sections were in use in the Peräpohjola area when the excavations for the construction of hydroelectric power plants were done in the Kemijoki basin. In these sections Korpela (1969) found organic deposits and sorted minerogenic sediments in between two till beds. Based on the Betula dominant microfossil content and ${ }^{14} \mathrm{C}$ age estimates, clustering around 40-50 ka ago, Korpela (1969) introduced the presence of an ice-free but quite cold substage known as the Peräpohjola Interstadial. This warmer stage was later correlated with the Brørup Interstadial in studies by for example Donner et al. (1986), Hirvas \& Nenonen (1987) and Hirvas (1991).

A comprehensive program of stratigraphical studies was carried out in the 1970's over northern Finland (Kujansuu, 1976; Hirvas, 1991), covering Finnish Lapland down to Rovaniemi in the south. Hirvas (1991) presented six glacial flow stages suggested to represent different glacial phases. Of these, only three phases were present in the stratigraphic record of southern Finnish Lapland (Hirvas, 1991; Sutinen, 1992) and the number of stadials and interstadials is still debatable. One researcher group suggests that only one Weichselian glacial advance existed, which covered most of Fennoscandia from the end of Eemian interglacial to the end of Late Weichselian deglaciation (e.g. Aario \& Forsström, 1979; Punkari, 1984; Forsström, 1991, 1995; Punkari \& Forsström, 1995). This interpretation also presumes that all organic inter-till beds are redeposited interglacial deposits, and that ice-free periods have not existed during the last glaciation. The second group presents that two glacial advances occurred during the Weichselian (e.g. Hirvas, 1991; Nenonen et al., 1991; Sutinen, 1992; Iisalo, 1992, 2003; Nenonen, 1995), divided by the Peräpohjola Interstadial. Furthermore, as a result of the latest investigations, it has been proposed three separate glaciations during the Weichselian in eastern Fennoscandia (Mangerud, 1991; Helmens et al., 2000; Svendsen et al., 2004).

The area investigated (Fig. 1) includes seven detailed study areas. The first aim of the work was to study the characteristics of till and glacial morpholo- 
gy and to compile glacial stratigraphy of the Weichselian glaciations/deglaciations in the area. Secondly, the results from the area have been used as a reference for the regional geomorphology in the southern Finnish Lapland area where the glacial history and dynamics have been reconstructed. The Quaternary lithostratigraphy with descriptions, formal names and type sections has been proposed. The stratigraphy of the Weichselian glacial deposits is also discussed.

\section{Bedrock and its relief}

The bedrock of the study area belongs mainly to the Paleoproterotzoic Peräpohja Schist Belt (Fig. 1), situated between the Archean Pudasjärvi Granite Gneiss Complex in the south and the Paleoproterotzoic Central Lapland Granitoid Complex in the north. At the southern boundary, a chain of layered mafic intrusions exists.
The Peräpohja Schist Belt is composed of metasedimentary rocks and several volcanic formations (Perttunen, 1989, 1991; Perttunen \& Hanski, 2003). The sedimentary rocks mainly consist of dolomites, mica schists, quartzites and conglomerates. Volcanic rocks include tholeiitic basalts, mafic tuffites and acid volcanic rocks. Mafic diabase dikes and sills are common, particularly in the quartzite units.

The bedrock of the Peräpohja Schist Belt has only a minor influence on the relief in large areas (Fig. 2). In many places, structural features like schistosity and tectonic movements control the morphology. The Kemijoki River, which flows through the study area, is situated on the northwest-southeast oriented fracture structure and forms the zone of topographic minimum $(63 \mathrm{~m}$ in the northeast and $29 \mathrm{~m}$ in the west above sea level (a.s.l)). The quartzites form the highest hills (e.g. Pisavaara $265 \mathrm{~m}$ and Vammavaara $228 \mathrm{~m}$ a.s.l), which clearly stand up from the

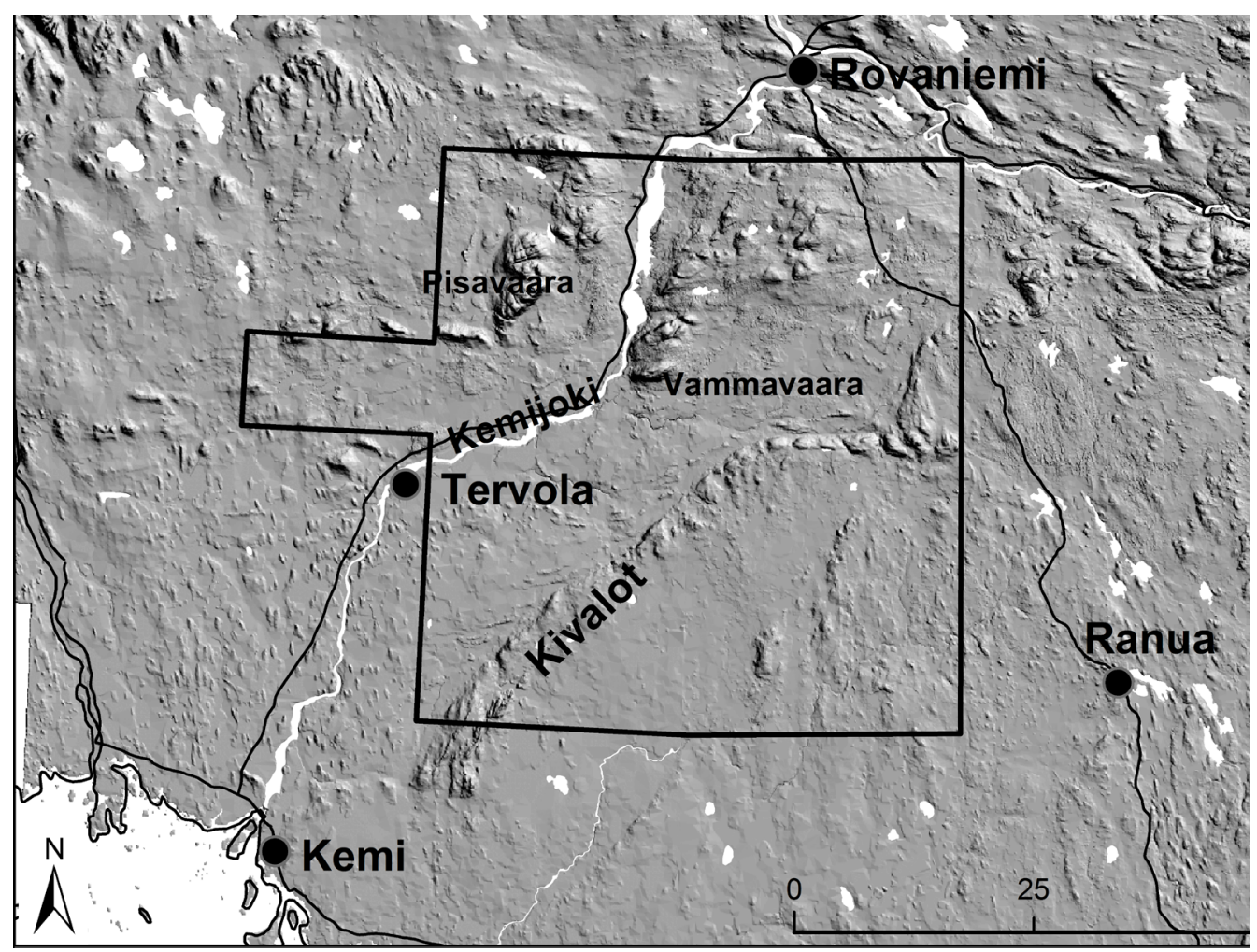

Fig. 2. A relief map of the area based on the elevation model. Streamlined glacial morphology is seen on the northern side of Kemi and Ranua and eastward from the town of Rovaniemi. The boundary between the Peräpohja Schist Belt and Pudasjärvi Granite Gneiss Complex is also seen as the Kivalot hill chain in the middle of the area. Elevation data (C) National Land Survey of Finland, permission number 54/LA/05. 
surrounding area. In the southern parts, where the difference in height is about $40-50 \mathrm{~m}$, the topography is steeply rising to the south when crossing the Kivalot hill chain. The granite gneisses of the Pudasjärvi Complex again form only a gently rolling relief in the south. Contrary to that, the granitoids in central Lapland form a hill and fell area with highly variable topography.

\section{Methods}

Aerial photographs and digital elevation model data have been used to identify different glacial and postglacial landforms and their distribution in the study area. Black and white 1:60 000 photographs were available for the whole study area. Four principle landform types were mapped: a) landforms indicating glacial flow direction (ribbed moraines, drumlins and flutings), b) other moraine types (non-oriented hummocks, ground and cover moraine areas) (cf. Aario, 1977a), c) eskers and other glaciofluvial deposits and d) post-glacial shore deposits.

Detailed fieldwork, including tractor excavations, was done at seven test sites. Till structure, fabric and striae orientations, together with sampling for grain size, geochemical, heavy mineral, pebble and surficial boulder composition/roundness analyses were used to estimate glacial debris transport directions and distances and to clarify the till stratigraphy at the test sites. In places supplementary bedrock mapping was carried out to help estimate transport distances. Furthermore, all available data from earlier works was compiled, for

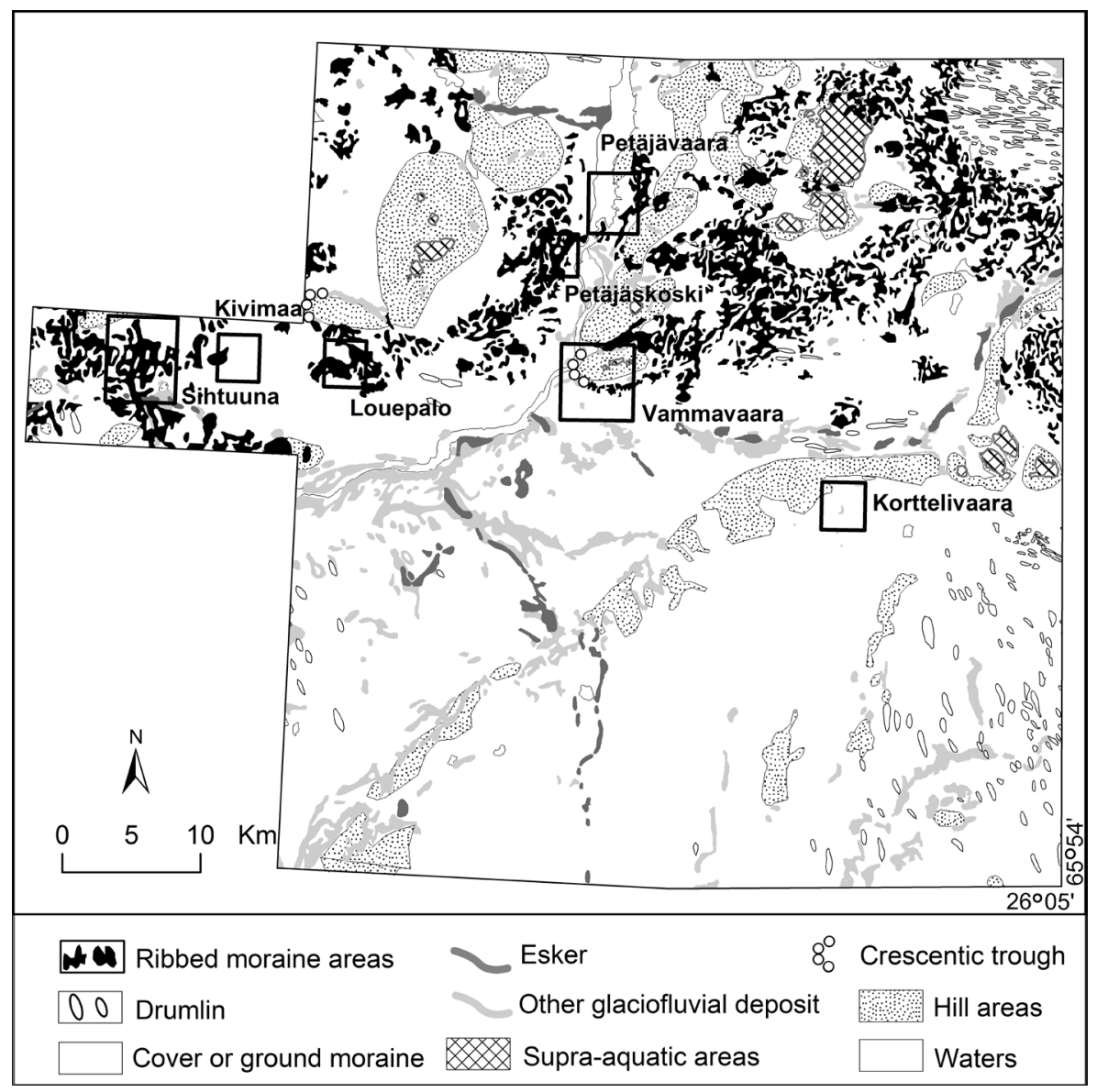

Fig. 3. Map of Quaternary deposits in the study area. Ribbed moraines and younger drumlins are common in the northern part of the area. In the southern part, cover moraines and older drumlins are more common. Topographic features (c) National Land Survey of Finland, permission number 54/LA/05. 


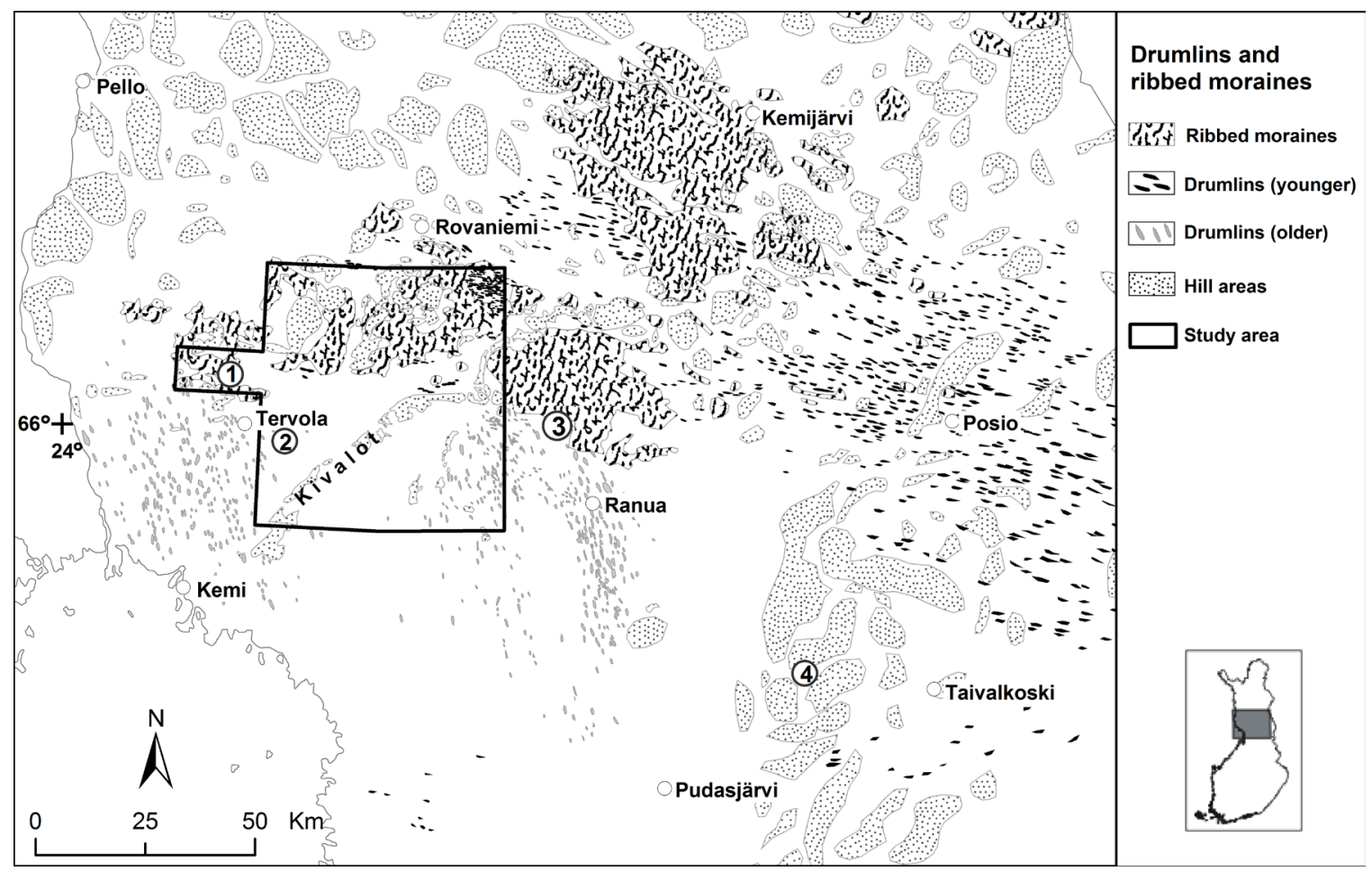

Fig. 4. The occurrence of drumlins and ribbed moraines in southern Finnish Lapland. The places mentioned in text are: I) Sihtuuna, 2) Kauvonkangas, 3) Portimojärvi and 4) Iso-Syöte.

example, striae and fabric observations done during earlier mapping and prospecting works with GIS software. All available chronological data was used to compare stratigraphical and palaeo-ice sheet evidence with emphasis on glacial morphological evolution and timetransgressive ice sheet reconstruction.

\section{Glacial morphology and flow di- rections in the study area}

\section{I. Morainic landforms}

Both parallel and transverse elements are present in the glacial morphology of the study area (Fig. 3). Under the active glacial flow, the glacier eroded bedrock and also deposited morainic landforms. The erosion forms, like rock drumlins and large, streamlined hills, indicate dominant glacial flow from the west to the east. Striae observations support that interpretation, particularly in the northern part of the area. In the south, glacial flow direction from the north- northwest or the northwest is dominant. In places, northern and western flow directions are seen in the same outcrops as cross-striae. A few observations of the crescentic trough (cf. Aario, 1977b) at the proximal, mainly western sides of the highest hills have also been done in the area.

The study area can be divided into two parts according to observed glacial activity. Active ice forms like transversal ribbed moraines are the most dominant landforms in the north (Fig. 3). Ribbed moraines (Fig. 4) exist as uniform fields on lowland areas and are mainly composed of Rogen moraine or hummocky ribbed moraine types (cf. Hättestrand, 1997; Sarala, 2003), but minor ribbed moraines also occur in the Sihtuuna area (cf. Aario et al., 1995, 1997). Ribbed moraines form together with drumlins and flutings as assemblages of active ice morphology (cf. Aario, 1977a, 1990; Lundqvist, 1969, 1989) (Fig. 4). Quartzite hills or hill areas occurring transversal to the general glacial flow break the uniformity of the ribbed mo- 


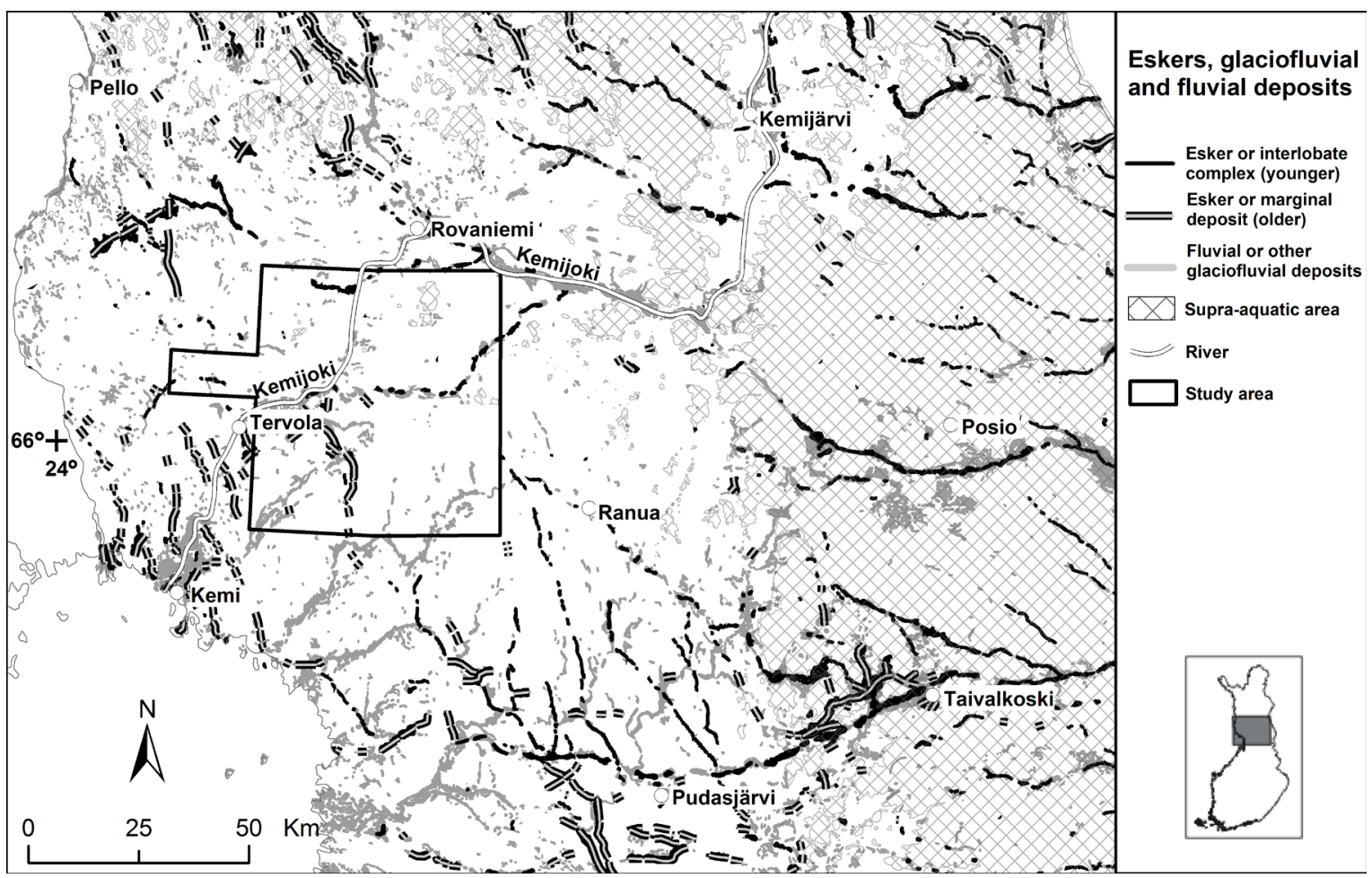

Fig. 5. The occurrence of eskers, glaciofluvial and fluvial deposits in southern Finnish Lapland. The areas above the highest shoreline of Ancylus Lake have also been marked on the map. Eskers of different ages have been separated from each other by colors; classification is based on Johansson (2005) and the reference within.

raine-drumlin field. Southern parts of the area indicate a more passive glacial activity during the latest glacial phase. A cover moraine (cf. Aario, 1977a) is the main landform type and it follows the bedrock surface forming gently undulating topography surrounded by mires. A partition of ground moraines increases to the south. In the southeast part of the area, drumlins occur with a northwest-southeast orientation. They are part of a large drumlin field in between the town of Kemi and the village of Ranua (Fig. 4).

\subsection{Glaciofluvial deposits}

Eskers and other glaciofluvial deposits are common in the north and in the middle of the area (Fig. 3) and indicate the trends of glacial flow direction during the last stages of deglaciation. Initially, the flow was from the west in the eastern part of the study area. As the margin retreated, the glacial flow direction changed to west-northwest $\left(280^{\circ}-290^{\circ}\right)$. The trend was also supported by fabrics in till and indicates the behaviour of ice lobes during the last deglaciation.

The esker chain at the northern side of the Kivalot (hill chain) deviates from the general glacial flow direction (Fig 5). The hill chain directed meltwaters to flow in proximal contact with the hill chain and thus the uniform, east-west oriented esker chain turned to the northeast at the eastern side of the study area. Farther to the east, the esker chain reached the Kemijoki basin (Fig. 5). During that time, the modern Kemijoki basin worked as a meltwater channel toward the east and southeast. It was not until the water level of the early Baltic Sea (Litorina Sea) decreased to a level below the centre of Rovaniemi 7 800-7 400 years before present (Saarnisto, 2005) that the modern Kemijoki River started to flow toward the southwest. In places, the west-southwest directions of striae, fabric and eskers in the middle of the study area, 


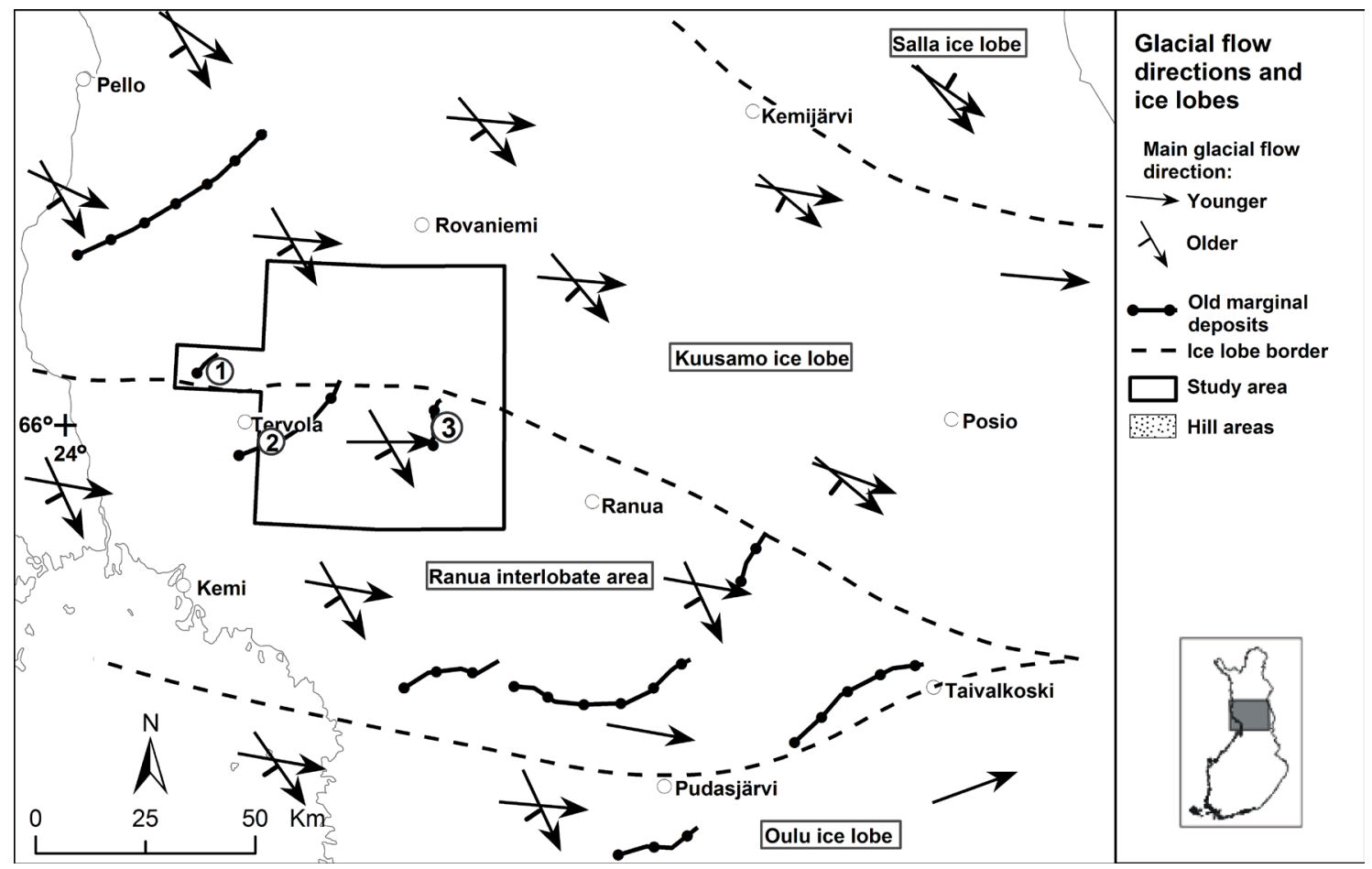

Fig. 6. Glacial flow directions, ice streams and the location of known, mainly till-covered marginal formations in southern Finnish Lapland. The places mentioned in text are: I) Sihtuuna, 2) Kauvonkangas, 3) Korttelivaara.

on the northern side of Kivalot, may be due to local glacial flow toward the east-northeast during the latest retreating stage.

Since the meltwater channel existed along the northern side of Kivalot, esker and other glaciofluvial formations are minor on the areas south to the hill chain. Only a few north-south oriented and tillcovered esker chains exist. Further to the south, esker chains seem to begin to grow once again toward to the southeast (Fig. 5). Later, under the influence of pro-glacial Ancylus Lake, the early stage of the Baltic Sea, the ice sheet melted away forming any specified moraine formations or marginal deposits. Different directions of esker chains on the northern and southern side of Kivalot also reflect the existence of separate ice lobes with different glacial dynamics.

\subsection{Marginal formations}

Based on the till stratigraphy and the existence of organic inter-till layers, Mäkinen (1985) and Sutinen
(1992) presented several marginal complexes older than the Late Weichselian glaciation from southern Lapland (Fig. 6). Tills from the last glacial advance mostly covered the complexes. Sutinen (1992) presented that the ice margin reached not farther than on the southern side of the town of Pudasjärvi from the north and is followed by a series of smaller formations closer to the ice-divide (towards the northwest) during the retreat phase. One of the marginal formations is situated in the middle of the study area (Fig. 6). The complex passes through Kauvonkangas near the village of Tervola and continues to the northeast. Kauvonkangas is known for Betula dominant peat layers of the Peräpohjola Interstadial within the glaciofluvial deltaic/esker complex, which exists as an inter-till deposit between two uppermost till beds in section (Mäkinen, 1979). Radiocarbon dates have given results of about $48 \mathrm{ka}$ for peat (Mäkinen, 1979), TL age estimations have been $74 \mathrm{ka}$ and $120 \mathrm{ka}$ for silts and sands beneath the peat and $55 \mathrm{ka}$ for sands below the peat (Punning \& Raukas, 1983). 
Fig. 7. Quaternary deposits, topography and location of test pits in the Petäjävaara area. Topographic features (C) $\mathrm{Na}$ tional Land Survey of Finland, permission number 54/LA/05.

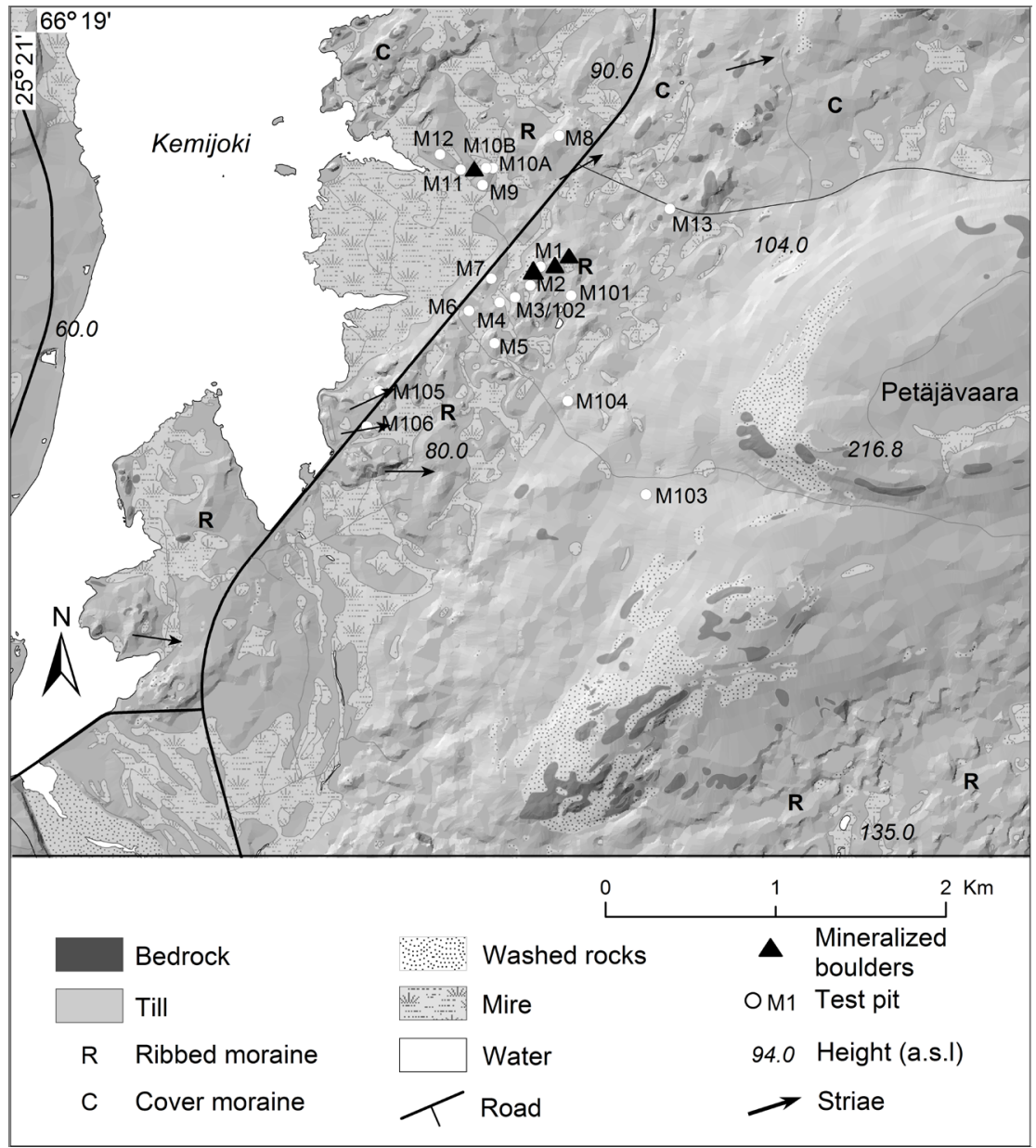

Two OSL dates have given results of $57+/-5 \mathrm{ka}$ for silt and $66+/-5$ ka for sand beneath the peat (Mäkinen, persunal commun. 2005).

During the latest deglaciation, the retreating phase was rapid and continuous and, together with the water body in front of the ice sheet, marginal formations were not formed (cf. Boulton et al., 2001). The highest shoreline of pro-glacial Ancylus Lake was at its highest about 215-219 $\mathrm{m}$ a.s.l.

\section{Description of the study sites}

\section{I. Petäjävaara}

The Petäjävaara site is situated on the eastern side of the Kemijoki River, about $30 \mathrm{~km}$ southwest of the centre of Rovaniemi (Fig. 7). The main working area is along the western slope of the Petäjävaara hill, about 70-90 $\mathrm{m}$ a.s.l. The landscape is composed of mires and rocky outcrops near the river and Rogen moraine ridges perpendicular to the last glacial flow direction with a bouldery surface on a higher level (cf. Sarala et al., 1998; Sarala \& Rossi, 1998). The top of the hill, which rises above $217 \mathrm{~m}$ a.s.l., is almost totally covered by shore deposits of the Ancylus Lake.

Two till units have been observed in the area (Fig. 8). The lower one (Fig. 9) was deposited under glacial flow from a north-northwest direction and consists of till material transported over a long distance. The massive structure with some fissility indicates deposition subglacially, mostly as lodgement till under thick ice depositional environment. The upper till unit with western or southwestern fabrics is composed of boulders and debris transported over a short-distance indicating deposition of the subglacial ice lobe phase. 

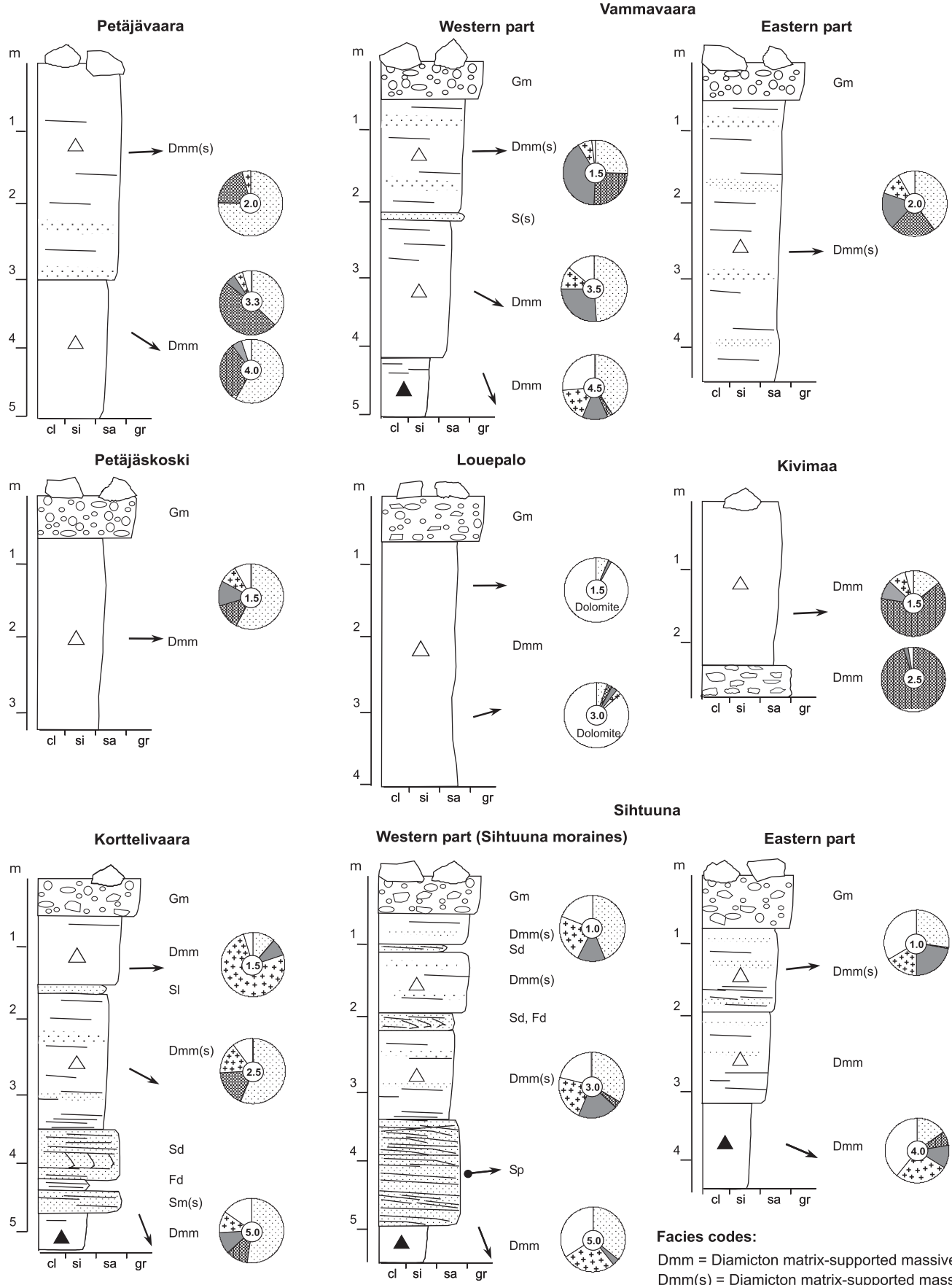

Sihtuuna

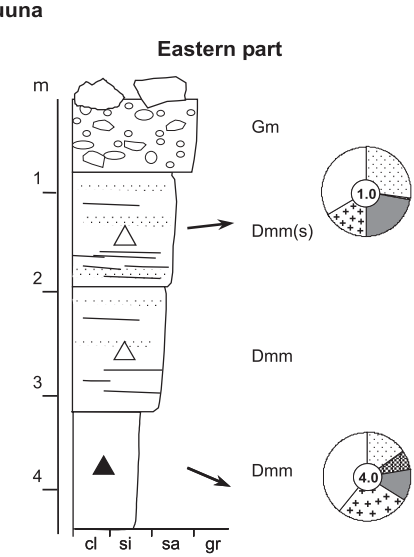

Facies codes:

Dmm = Diamicton matrix-supported massive $\operatorname{Dmm}(\mathrm{s})=$ Diamicton matrix-supported massive, $\mathrm{Gm}=$ Gravel matrix-supported massive $\mathrm{Fd}=$ Fines deformed

$\mathrm{Sp}=$ Sand planar cross-bedded

$\mathrm{Sd}=$ Sand deformed

$\mathrm{S}(\mathrm{s})=$ Sand sheared

$\mathrm{Sm}(\mathrm{s})=$ Sand massive (sheared)

$\longrightarrow$ Palaeoflow direction (current induced structures)

$\mathrm{SI}=$ Sand laminated

Fig. 8. Composition profiles of test pits and stratigraphical interpretation of sedimentary units in the test sites. 


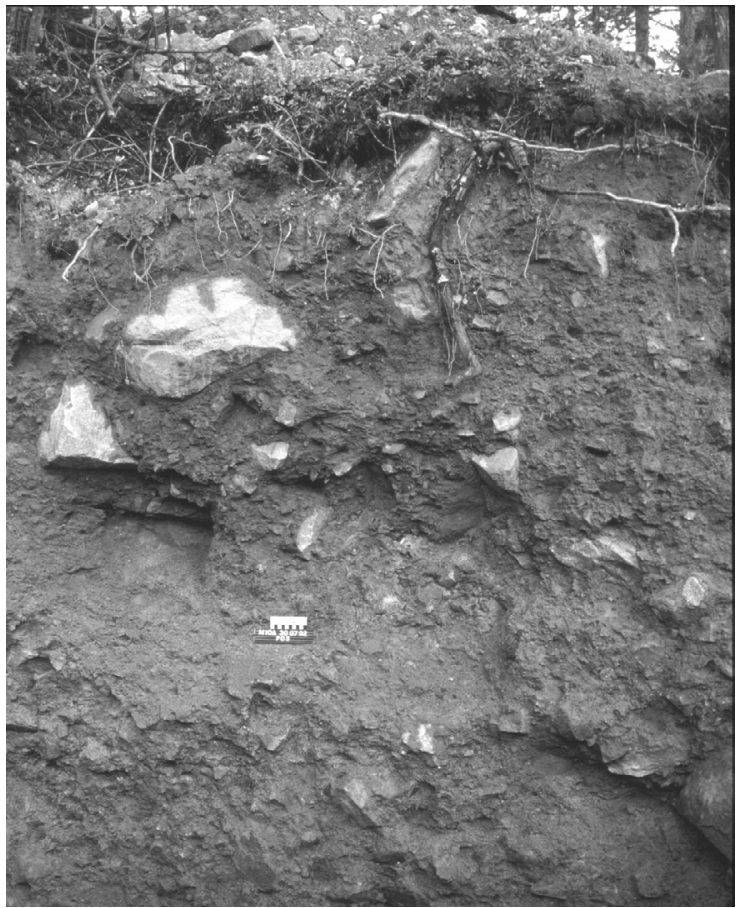

Fig. 9. Two till units in test pit MIOa at the Petäjävaara site. The boundary between till units exists above the scale sign.
Particularly, boulders and rock fragments in a surficial till unit (Fig. 10) and above the ridges represent very short transportation resulting from strong glacial gouging action at the end of deposition. Glacial flow directions are also seen in the striation, where western directions are most common.

\subsection{Vammavaara}

Vammavaara is one of the highest hills (about $228 \mathrm{~m}$ a.s.l.) in the study area. The top has been in a supraaquatic position, while the highest shoreline reached about $215 \mathrm{~m}$ a.s.l. during the Ancylus Lake stage. The main working area is along the southern side of the hill 60-120 m a.s.l (Fig. 11). Ribbed moraine morphology is dominant in the middle of the site and a cover moraine and dead-ice hummocks are also present in southern parts (Sarala et al., 1998).

The ribbed moraine ridges consist mainly of hummocky ribbed moraines and Rogen moraine types composed of three till units (Fig. 8). The lowest unit

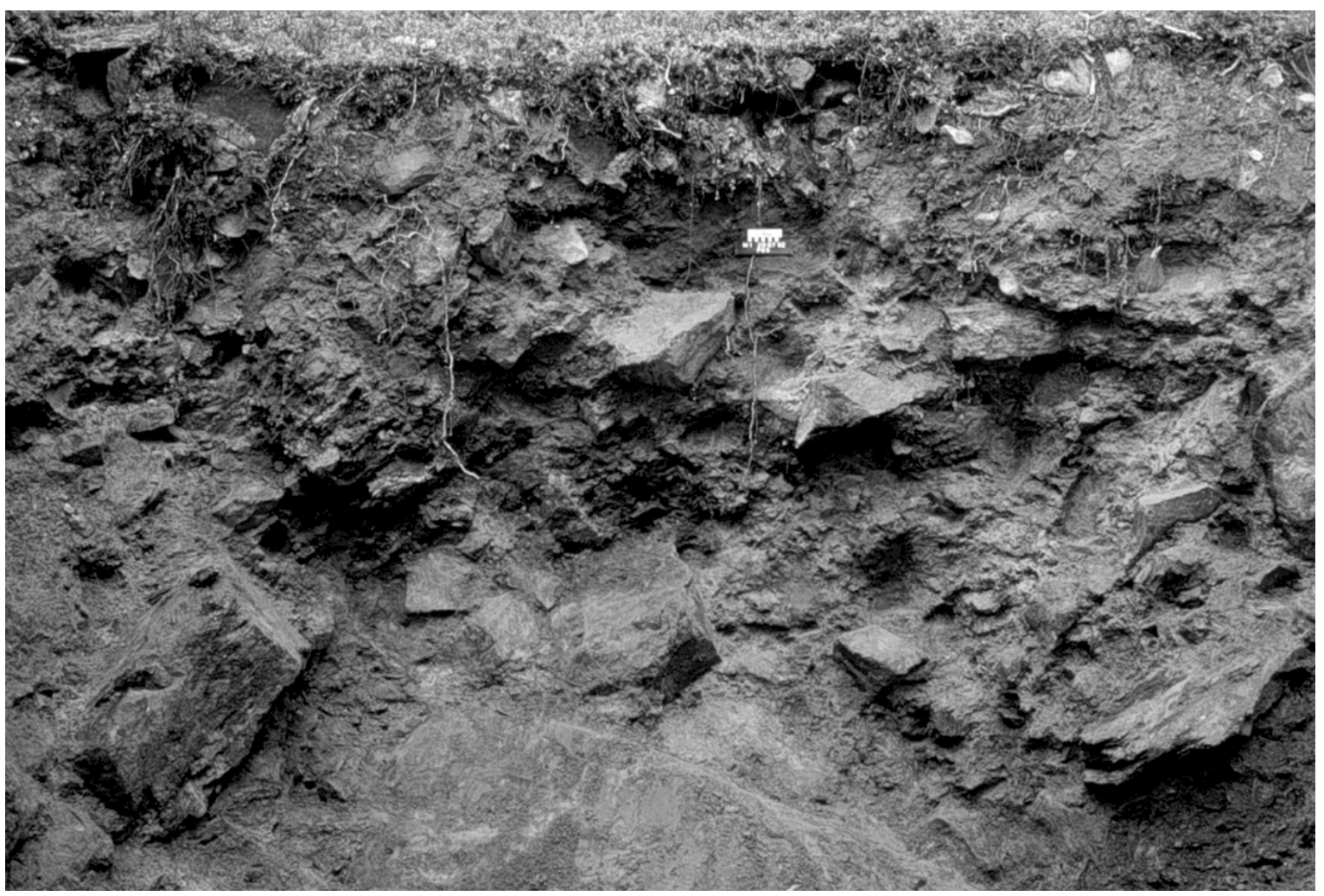

Fig. I0. Bouldery till in test pit MI at the Petäjävaara site. 




Fig. II. Quaternary deposits, topography and location of test pits in the Vammavaara area. Topographic features (C) National Land Survey of Finland, permission number 54/LA/05.

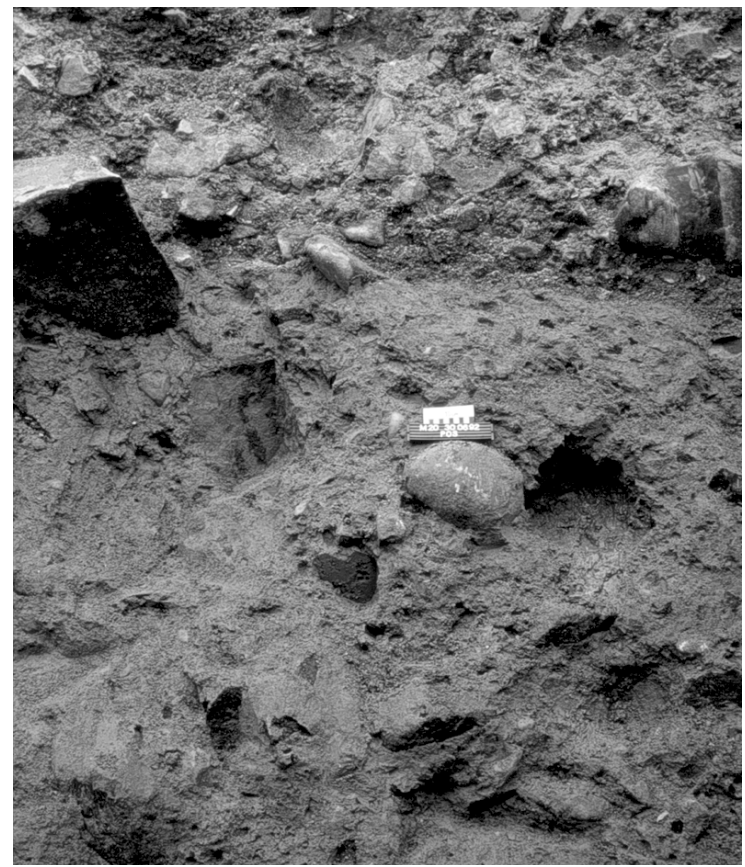

Fig. 12. Compact, bluish grey till in test pit M20 at the Vammavaara site. Contact to the upper shore deposit is sharp above the scale sign. 
Fig. 13. Sharp contact between two uppermost till units in test pit M25 at the Vammavaara site.

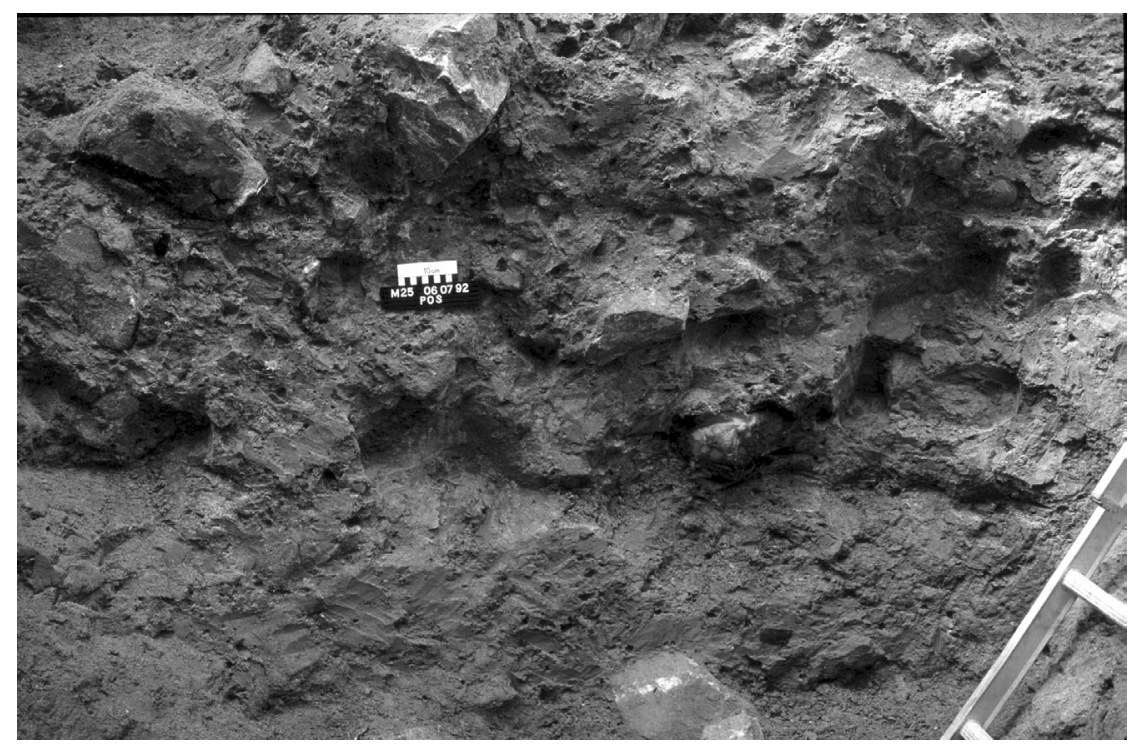

is a dark bluish grey till with a very dense package (Fig. 12). The overall feature is a massive structure with some fissility or fine-grained laminae occurring in the upper parts of the unit. The matrix is fine-grained sand and relatively clay-rich (7\%). Pebbles are rounded and composed of a wide variety of rock types mostly indicating long glacial transport from a north-northwest direction. The second, sandy till unit was deposited under glacial flow from the west-northwest including lenses of bluish grey till. It has mainly composed of fartravelled debris. A massive structure with some finegrained laminae and sand lenses indicates subglacial deposition, mostly as lodgement till. The upper till has a variable composition and structure. Fabric analyses showed that glacial flow was from the west to the east. Contact between the till units is sharp (Fig. 13).

In western parts, glacial erosion was effective because a crescentic proximal trough (in Fig. 11) was formed (cf. Aario, 1977b). As a result, the glacier removed surface of the bedrock. The transported material was deposited into the ribbed moraine ridges on southern side of the Vammavaara hill so that the amount of fine-grained material decreases towards the east. In the western part, an intermediate layer of till material existed consisting of weathered bedrock that was fully composed of mafic volcanic rocks deriving from the bedrock only a few hun- dreds of meters to the east. The proportion of local rock fragments in the uppermost till and at the surface of the ridges was still characteristic of the ribbed moraines.

\subsection{Petäjäskoski and Louepalo}

The Petäjäskoski (Fig. 14) and Louepalo (Fig. 15) sites are situated in the middle of the study area that is typical area for Rogen moraines. Both sites are on a lowland area (70-90 $\mathrm{m}$ a.s.l.), only a few kilometers from the Kemijoki River to the west. The bedrock is composed of mafic volcanic rocks, diabases and quartzites in the Petäjäskoski area (Perttunen \& Hanski, 2003). However, the Louepalo site is situated over dolomite bedrock. At both test sites, the till unit observed in the test pits is composed of sandy matrix with western till fabrics and a short transport distance for the rock fragments (Fig. 8).

\subsection{Kivimaa}

The glacial morphology at the Kivimaa site is commonly composed of only one meter or less thick till cover, although in depressions and mires the thickness can be several meters. The topography of the Kivimaa hill is gently rolling and the till cover is due 

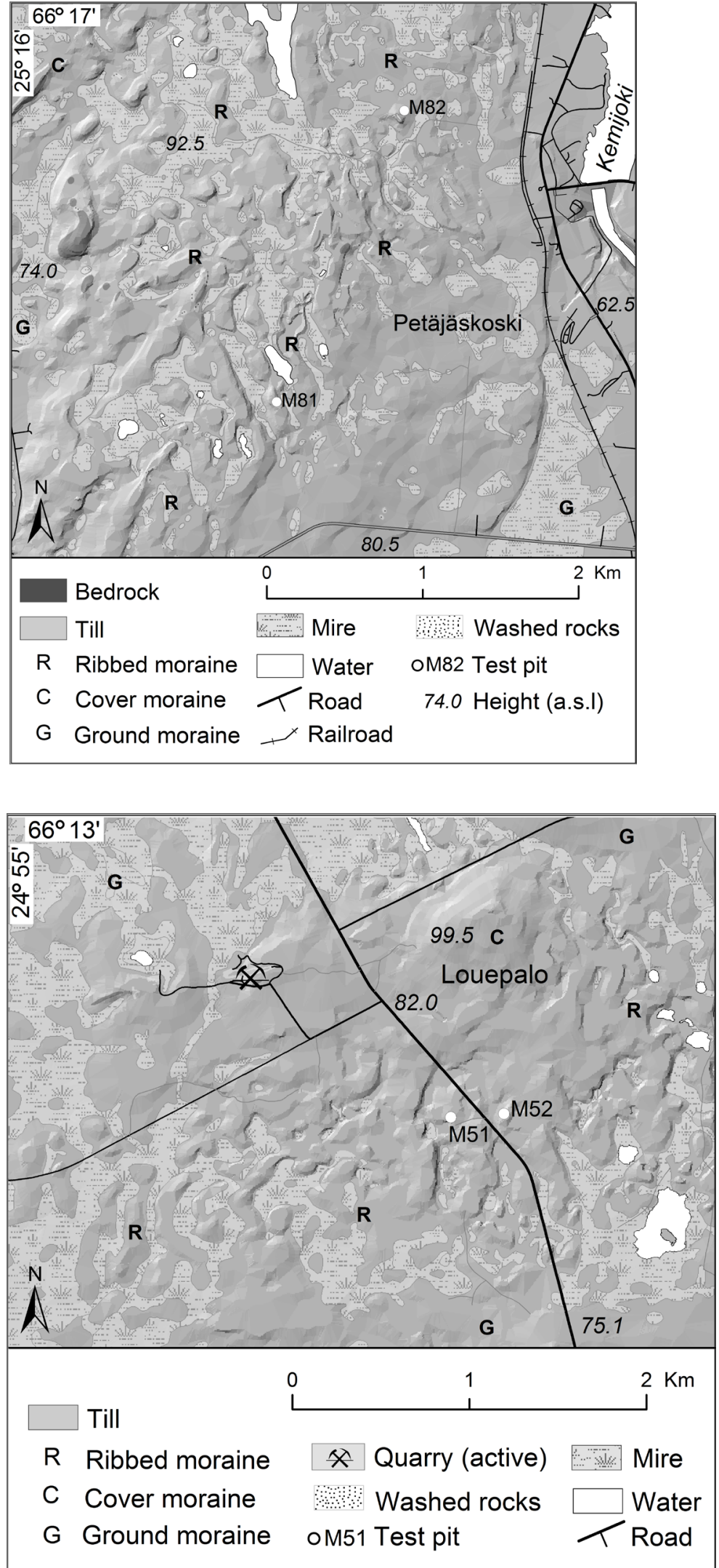

Fig. 14. Quaternary deposits, topography and location of test pits in the Petäjäskoski area.Topographic features (C) National Land Survey of Finland, permission number 54/LA/05.
Fig. 15. Quaternary deposits, topography and location of test pits in the Louepalo area.Topographic features (c) National Land Survey of Finland, permission number 54/LA/05. 
Fig. 16. Quaternary deposits, topography and location of test pits in the Kivimaa area. Topographic features (C) National Land Survey of Finland, permission number 54/LA/05.

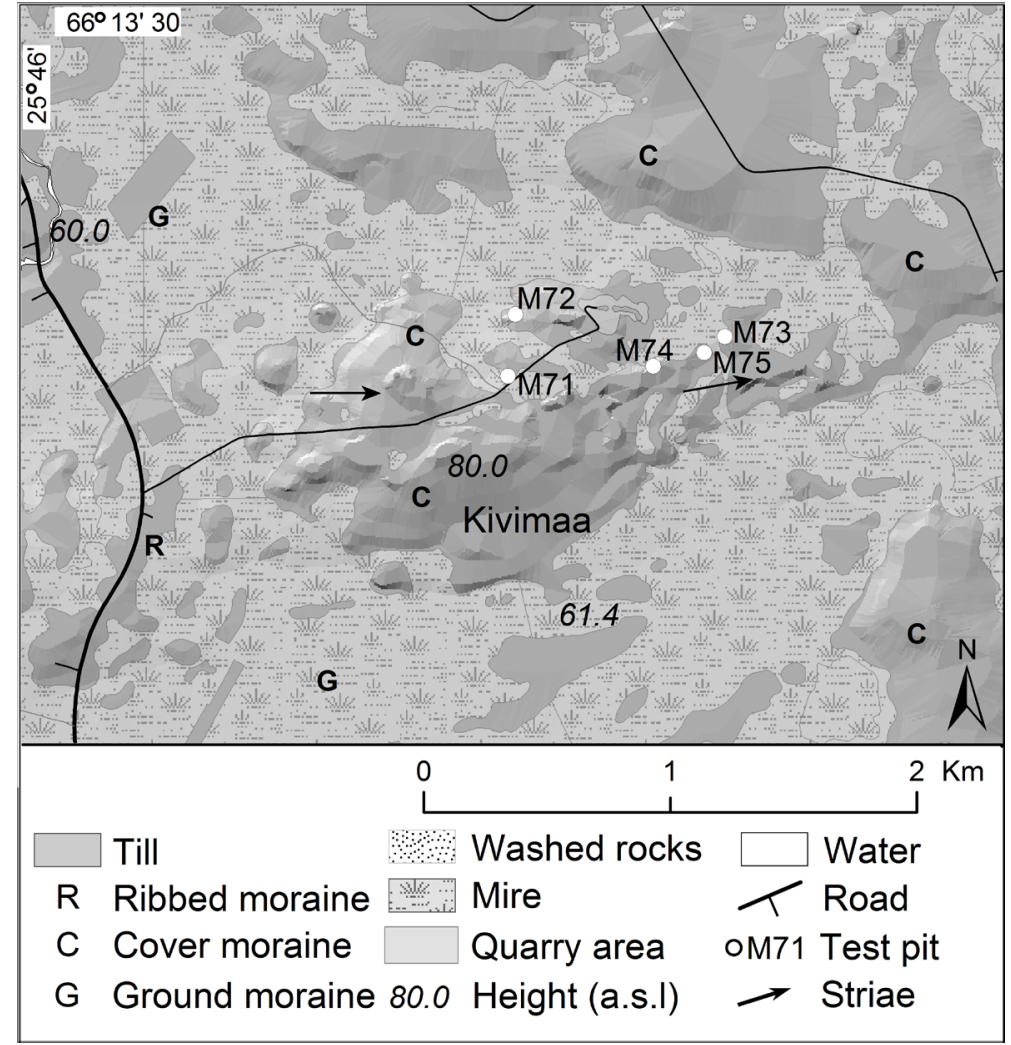

to the major topographical depression of the underlying bedrock (Fig. 16). The uppermost till unit is composed of loose and massive sandy till (Fig. 8) with fabrics and striae showing the glacial flow from the west. The till changes to bouldery and clast-supported till material (Fig. 17) resembling weathered crust under a depth of 1-2.5 m. The petrographic composition of angular boulders and other rock fragments is al- most totally the same as in the underlying diabase. The bouldery surface of the lower till is the effective limit for till sampling.

\subsection{Sihtuuna}

The Sihtuuna area was interesting because the ridge morphology perpendicular to the latest glacial flow re-
Fig. 17. Bouldery, clast-supported till material in test pit M7I at the Kivimaa site. The rock type of angular boulders and other rock fragments is almost totally the same as in the underlying diabase bedrock.

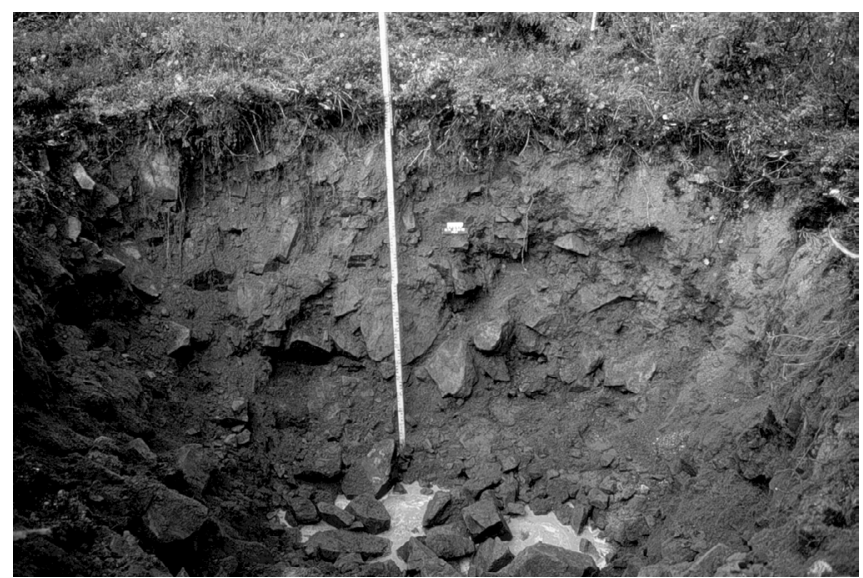




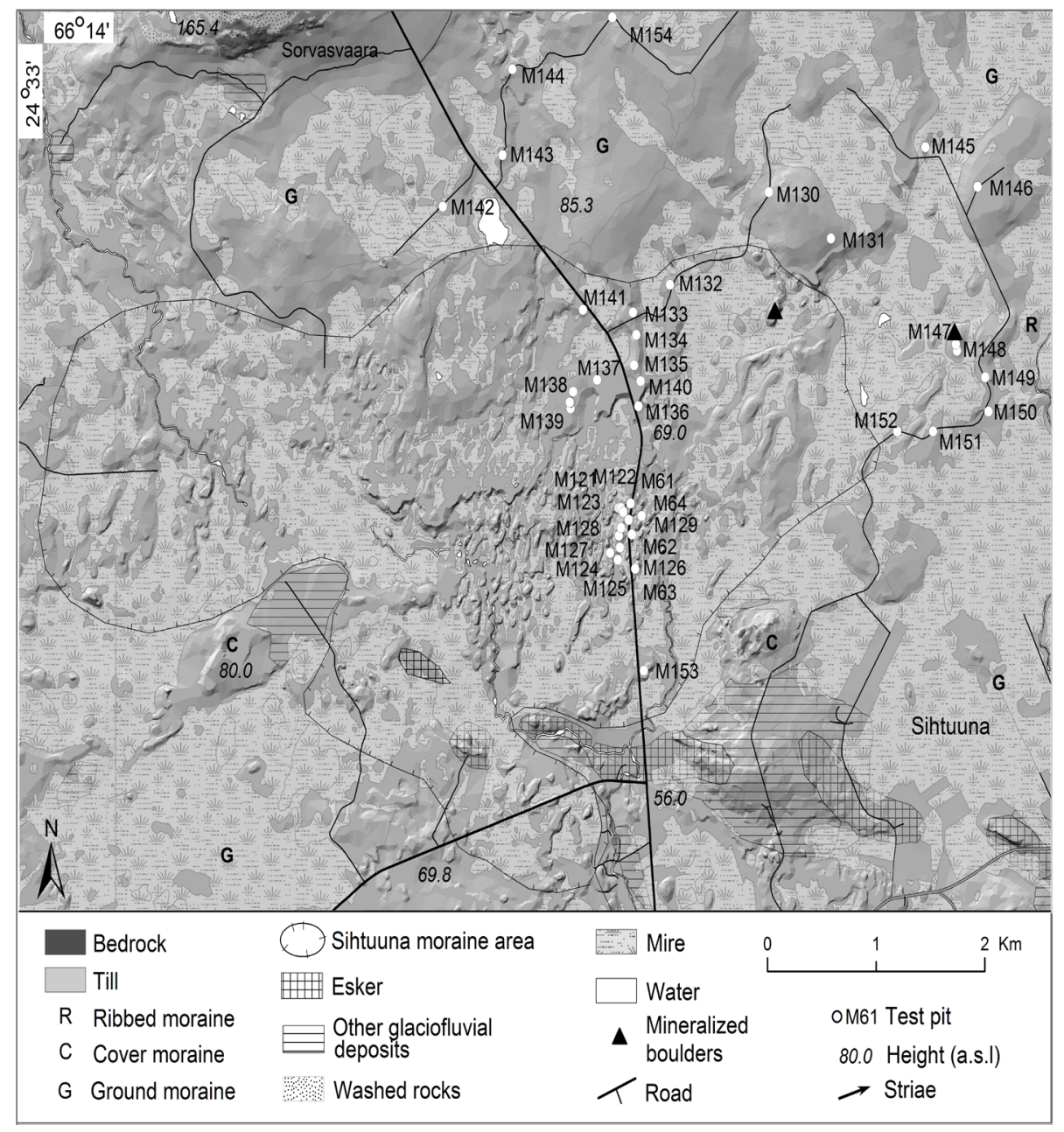

Fig. 18. Quaternary deposits, topography and location of test pits in the Sihtuuna area. Topographic features (c) National Land Survey of Finland, permission number 54/LA/05.

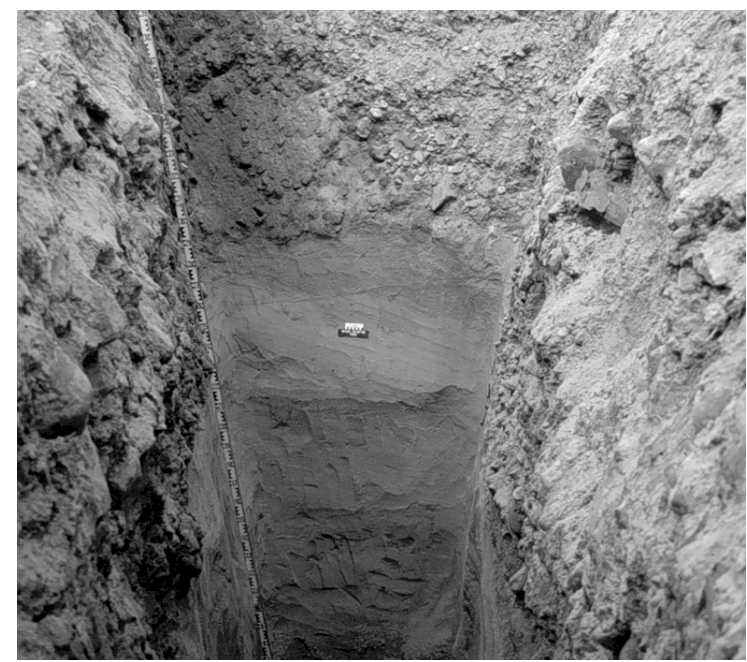

Fig. 19. Stratified sands above bluish grey till unit in section MI24 at the Sihtuuna site. Gravelly till and shore deposit cover the sands. 


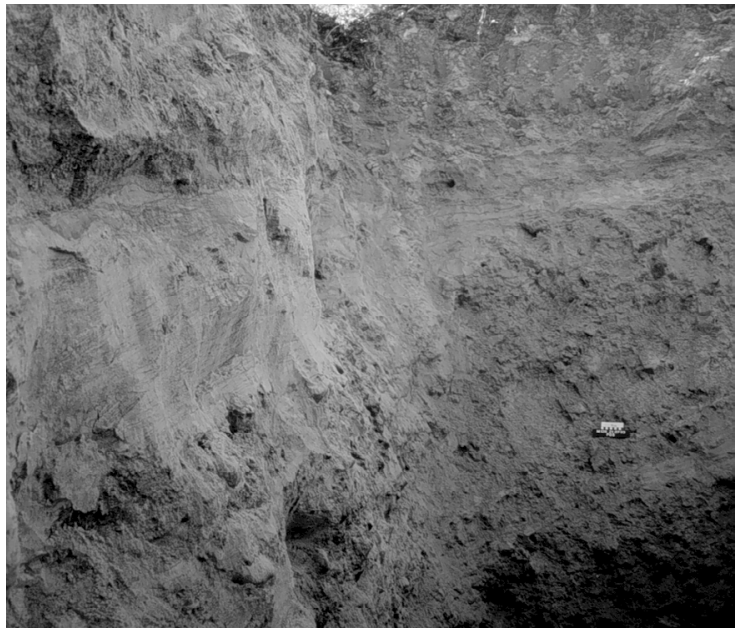

Fig. 20. Sandy layers in between till units in section MI28 at the Sihtuuna site.

sembles Rogen moraines (Fig. 18). An assemblage was named the Sihtuuna moraine by Aario et al. (1995). The Sihtuuna assemblage covers about $10 \mathrm{~km}^{2}$ but separate ridges are relatively small in scale; several hundreds of meters long, some tens of meters wide and 3$5 \mathrm{~m}$ high. The ridges are composed of several stratigraphical units (Fig. 8). On the bottom is a bluish grey till unit with a consolidated, sandy or fine-grained matrix. It is massive in structure and the pebble orientation shows glacial flow from the northwest. Round pebbles with a large variation of petrographic composition indicate a distant source for debris.

The stratified sand deposit with planar bedding or small-scale cross-lamination exists above the bottommost till unit (Fig. 19). For example, in test pit M124 (Fig. 18) beddings gently dip to the east $\left(80^{\circ}\right.$; dip $\left.5^{\circ}-10^{\circ}\right)$ or the northeast $\left(50^{\circ}\right.$; dip $\left.15^{\circ}\right)$. The sand deposit is $1-2 \mathrm{~m}$ thick and has been observed in many test pits. Stones are rare although some drop stones exist in the upper parts of the sediment unit. The uppermost part of the sand deposit is glacially deformed and includes, for example, glaciotectonic shear planes and faults that have been affected by the glacier.

The second till unit follows sands in succession. The matrix of this till unit is sandy or even gravelly, although the composition and structure are het-

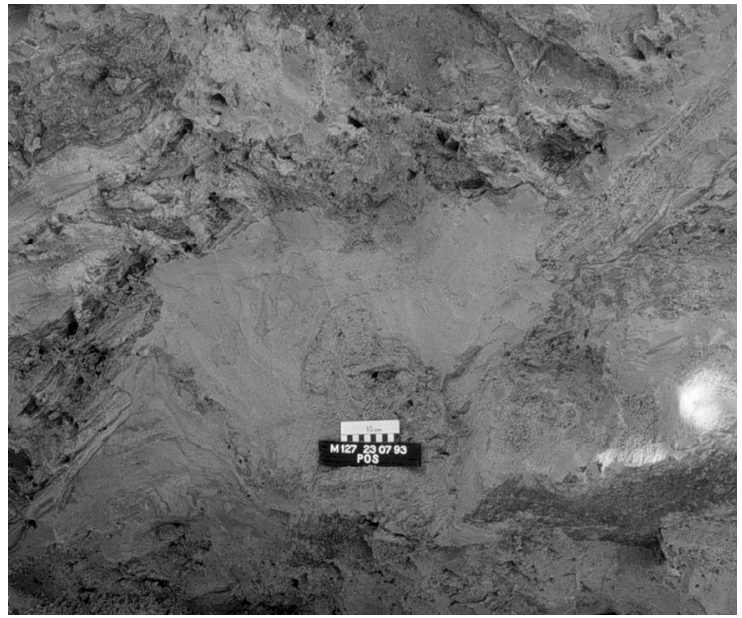

Fig. 2 I. Faulted sand lens with involution structures at a depth of about $1.5 \mathrm{~m}$ in section MI27 at the Sihtuuna site.

erogeneous; many sandy lenses and layers together with fine-grained laminae occur (Fig. 20). The lenses and layers typically include glaciotectonic deformation structures like shear planes and faults. Some thicker lenses include bagged features, which are similar to involution structures caused by cryoturbation (Fig. 21). These features are typically formed under periglacial conditions (cf. Lagerbäck, 1988b). They cannot have formed after the Late Weichselian, because the area was submerged thousands of years after deglaciation. Also, during the Holocene the climate did not favor the formation of those structures. In the upper parts of the second till unit has a gravelly, stratified sediment layer or gravelly, pebble rich till material that was found in many test pits.

The composition of the uppermost part of the ridges, from the depth $1-1.5 \mathrm{~m}$ to top, is gravelly and heterogeneous in its structure (Fig. 19). In places, till is hard to distinguish from the shore deposits. Material can be classified as till when it is debris-supported and has features like fine-grained laminae, shear planes and faults as a marker of glaciotectonic deformation. If material is gravelly, massive in structure and mainly clast-supported, it can be the shore deposit of the later Ancylus Lake. The great amount of local boulders both in the uppermost unit and at the surface is a reminder of relation to ribbed moraines. 


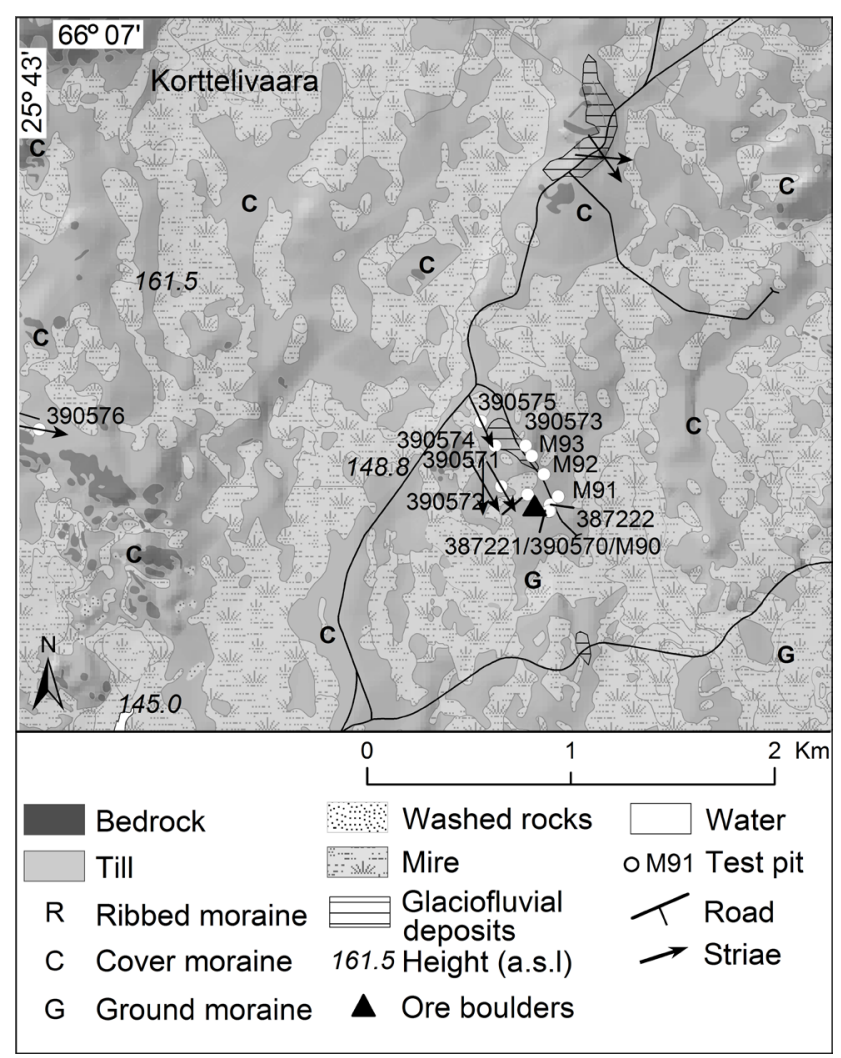

Fig. 22. Quaternary deposits, topography and location of test pits in the Korttelivaara area.Topographic features (C) National Land Survey of Finland, permission number 54/LA/05.

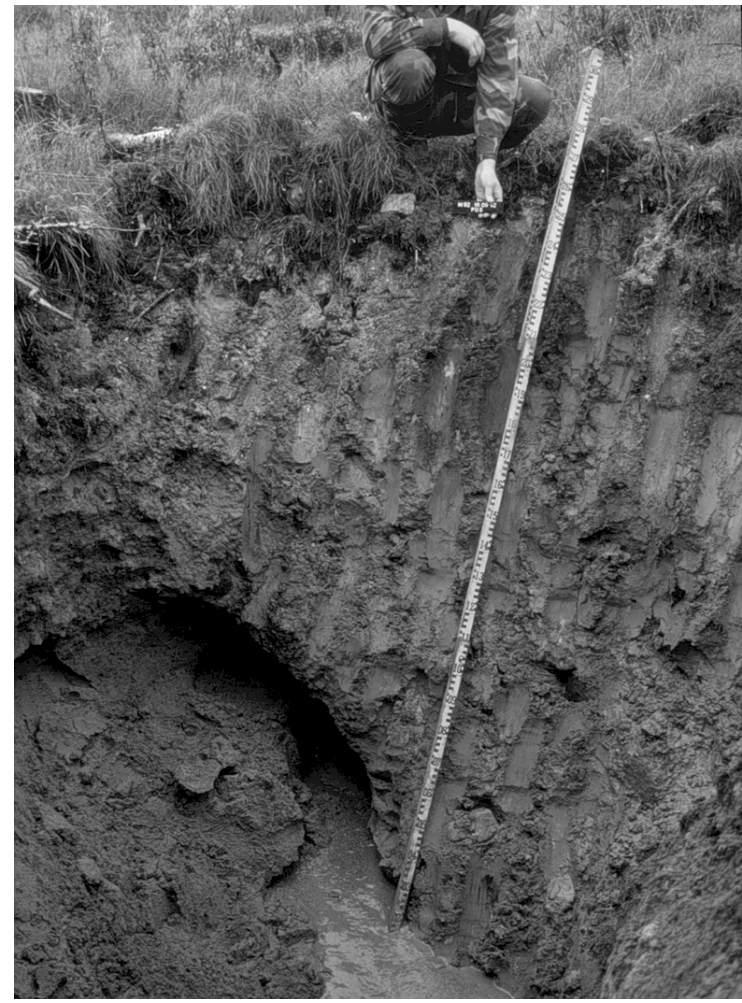

Fig. 23. Till-covered sandy deposit in section M92 at the Korttelivaara site.
Cross-sections through the ridges prove that the Sihtuuna moraines are depositional formations, not push or squeeze forms. Structures and beddings in the sedimentary units and upper tills evenly follow the outer ridge form. Due to the sandy or even gravelly matrix of upper tills with sandy lenses and intermediate layers, one of the sources must have been stratified sediment. Since the formation process of ribbed moraines favors quarrying (cf. Aario \& Peuraniemi, 1992; Sarala \& Rossi, 1998, 2000), the sandy material in upper tills is mostly a result of redeposition of sediments between the ridges. Part of the sandy lenses and layers may also have been deposited because of the melt-waters and mass-flow of sediments existing during formation (cf. Aario et al., 1997). Due to the lack of relation with drumlins or drumlinized elements and the more narrow and lower shape, Sihtuuna moraine ridges cannot be directly compared with Rogen moraines, but the description is suitable for minor ribbed moraines (cf. Hätterstrand, 1997). 


\subsection{Korttelivaara}

The Korttelivaara test site is the only one situated on the Archean Granite Gneiss area (Fig. 22). The distance to the Peräpohja Schist Belt is about five kilometers towards the last glacial flow direction. The surface of the bedrock is gently undulating and the overlying glaciogenic sediments form the cover moraine morphology.

Till stratigraphy is mostly composed of three till units (Fig. 8) of which the lower one is compact bluish grey, relatively clay-rich (7 \%) till with far-travelled pebbles oriented from the northwest to the southeast (cf. Vammavaara and Sihtuuna site). The second till unit is compact grey sandy till with sandy lenses and laminae. Shear structures and faults are common in upper parts of the unit. Pebbles are rounded having great partition of rock types travelled far from the Peräpohja Schist Belt instead of local granites. As compactness and structures show, these tills were deposited mainly as a lodgement till. The third, sandy till is homogenous and loosely packed having rounded pebbles and boulders of which composition represents quite local bedrock composition. Clear fabric shows west-east orientation.

In the middle of the test site exists northeast-southwest oriented stratified sand deposit, which is almost totally till-covered (Fig. 23) except for the central areas, where there is only a thin layer of shore deposit of Ancylus Lake above the sands. The thickness of the deposit was at its highest about 4-5 meters (observation from the earlier percussion drilling done by GTK) but in the test pits 1-2 meters. Planar or gently gross beddings are sediment structures in deposit. In places sand deposits are exposed and can be followed in some sand pits on the northern and southern sides of the test site.

\section{Quaternary lithostratigraphy and flow directions}

Based on observations made from the test areas and the published data (cf. Kujansuu, 1967; Korpela, 1969; Mäkinen, 1979; Sutinen, 1992; Hirvas, 1991), three till beds with two inter-till layers including organic material have been observed in southern Finnish Lapland (Fig. 24). Lithostratigraphy, descriptions and formal names in the area of Peräpohjola are presented in Table 1 and their correlation in Table 2. A whole stratigraphical sequence is proposed to name the Peräpohja Group.

Two observations of the lowest and oldest till bed, not found during the present study have been presented, one from Kauvonkangas, near the village of Tervola (Mäkinen, 1979) and another from Saarenkylä, of the centre of Rovaniemi (Sutinen, 1992). The till, named the Saarenkylä Till (Sutinen, 1992), is grey and very compact in structure and was deposited during the west-southwest glacial flow. The same direction is also seen in striations observed from the area and from western Lapland (Kujansuu 1967; Hirvas 1991). The Saarenkylä Till was interpreted to be from the Saalian glaciation (Sutinen, 1992). This correlates well with till stratigraphy from central Lapland (Till bed IV), where numerous observations of older till beds and inter-till layers have been identified (e.g. Hirvas \& Nenonen, 1987; Hirvas, 1991; Helmens et al., 2000). This area has repeatedly been the core area of glaciers.

Above Saarenkylä Till exist about $2 \mathrm{~m}$ thick Saarenkylä Gytja composed of organic gytja and silt (Sutinen, 1992). Based on Pinus- and Betula-rich pollen content but rather low Alnus amount and the absent of Quercus, this gytja can be interpreted as Eemian or Early Weichselian deposit.

The second till bed, named the Kemijoki Till (Sutinen, 1992), which in the present study occurs as the lowest till unit at the test sites at Korttelivaara, Sihtuuna and Vammavaara, is characteristically bluish grey in color. The very compact structure is due to the clay-rich matrix and overconsolidation caused by the glacial override. The amount of organic material is also high, because this till bed is the first one deposited after the Eemian interglacial and it includes, for example, bottom sediments from marine and lacustrine environments (cf. Iisalo, 1992, 2003). This till bed correlates with the so-called dark till (cf. Rainio \& La- 


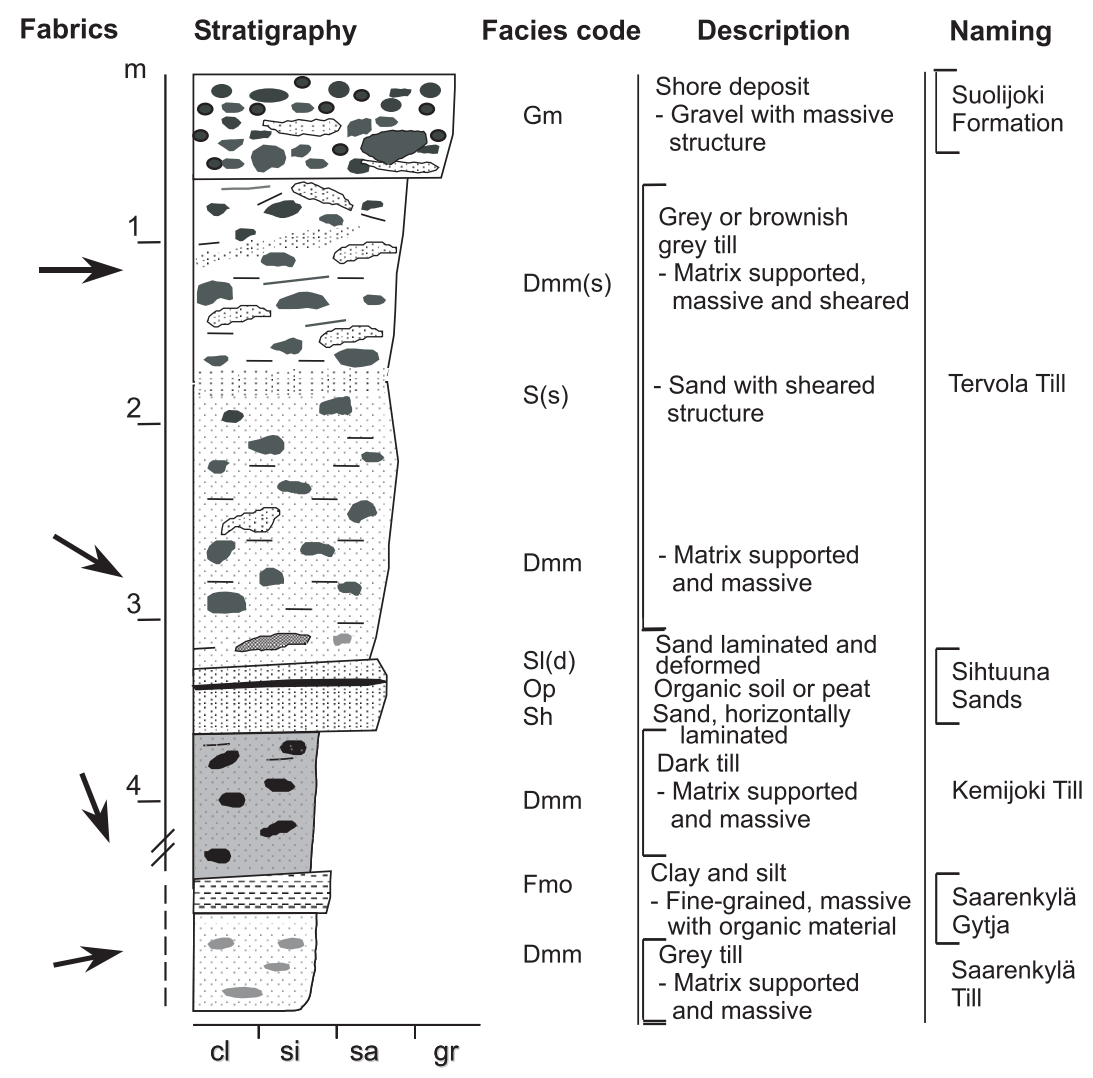

Fig. 24. Generalized stratigraphy of the study area showing various lithofacies and their interpretation and correlation. Stratigraphy is a composition of observations made during present study and earlier presentations in the literature (e.g. Korpela, 1969; Mäkinen, 1979; Aario, 1990; Sutinen, 1992). Arrows depict mean glacial flow direction in different till units.

hermo, 1984) and was at first time described by Korpela (1969) from the Kemijoki basin. Later, Aario \& Forsström (1979), Hirvas (1991) and Sutinen (1992) completed many observations of the till in southern Finnish Lapland. Sutinen (1992) interpreted the Kemijoki Till to be deposited during the Early Weichselian glaciation, when the margin of ice sheet reached only to the Pudasjärvi area. The general flow direction during this glacial advance was to the southeast. Also Ber \& Kujansuu (1974), Mäkinen (1979) and Hirvas (1991) presented this till bed as the first Weichselian till bed in the area.

Afterwards, the climate became somewhat warmer and the ice melted away from the Peräpohjola area. Korpela (1969) described fine-grained sediment units and organic layers of Peräpohjola Interstadial above the Kemijoki Till to be in situ. Some observations, in which the deposits are also interpreted to be in situ, have been done from the central Lapland (Hirvas \& Nenonen, 1987; Helmens et al., 2000). The sand deposit called the Sihtuuna Sands within the Sihtuuna moraine ridges can be interpreted to be an interstadial deposit based on the glaciotectonic faults and shear structures at surficial parts of the sands as a mark of glacial re-advance and the existence of periglacial involution structures in the redeposited sand lenses and layers.

The third till bed, Tervola Till, is composed of three till units (till members) (Fig. 25). A lower till member, Vammavaara Till, is grey, compact sandy till having well-developed fabric towards the southeast or the east. Sandy layers and laminae with shear structures in the surficial parts indicate deposition as lodgement till. The second till member, Petäjävaara 
Table I. Quaternary lithostratigraphy, unit descriptions and formal names in Rovaniemi-Tervola area.A whole stratigraphic sequence is proposed to name as the Peräpohja Group.

\begin{tabular}{|c|c|c|c|c|c|c|}
\hline Formation & Member & Depth & Description & Interpretation & $\begin{array}{l}\text { Chrono- } \\
\text { stratigraphy }\end{array}$ & Type section \\
\hline $\begin{array}{l}\text { Suolijoki } \\
\text { Formation }\end{array}$ & & $0.5-2 \mathrm{~m}$ & $\begin{array}{l}\text { Stratified sand } \\
\text { and gravel }\end{array}$ & Shore deposit & Holocene & \begin{tabular}{|l} 
N7345.5 I2561.5 \\
M118, Vammavaara
\end{tabular} \\
\hline \multirow{3}{*}{$\begin{array}{l}\text { Tervola Till } \\
\text { Formation }\end{array}$} & \begin{tabular}{|l|} 
Korttelivaara \\
Till Member \\
\end{tabular} & $0.1-1.5 \mathrm{~m}$ & $\begin{array}{l}\text { Brownish grey } \\
\text { sandy diamict }\end{array}$ & $\begin{array}{l}\text { Melt-out, flow or } \\
\text { waterlain till } \\
\end{array}$ & \multirow{3}{*}{ Late Weichselian } & $\begin{array}{l}\text { N7334.0 I3444.6 } \\
\text { M90, Korttelivaara }\end{array}$ \\
\hline & \begin{tabular}{|l|} 
Petäjävaara \\
Till Member \\
\end{tabular} & $1-3 m$ & $\begin{array}{l}\text { Brownish grey or } \\
\text { grey gravelly diamict }\end{array}$ & $\begin{array}{l}\text { Lodgement or } \\
\text { basal melt-out till } \\
\end{array}$ & & $\begin{array}{l}\text { N7358.5 I2564.1 } \\
\text { M1, Petäjävaara } \\
\end{array}$ \\
\hline & $\begin{array}{l}\text { Vammavaara } \\
\text { Till Member } \\
\end{array}$ & $1-4 m$ & Grey sandy diamict & Lodgement till & & $\begin{array}{l}\text { N7346.2 I2561.2 } \\
\text { M25, Vammavaara } \\
\end{array}$ \\
\hline \begin{tabular}{|l|} 
Sihtuuna \\
Sands \\
\end{tabular} & & $1-2.5 m$ & $\begin{array}{l}\text { Horizontally or cross } \\
\text { bedded sand }\end{array}$ & Subaquatic fan & $?$ & $\begin{array}{l}\text { N7344.6 I2529.6 } \\
\text { M124, Sihtuuna }\end{array}$ \\
\hline \begin{tabular}{|l|} 
Kemijoki Till \\
Formation \\
\end{tabular} & & $1-2 m$ & $\begin{array}{l}\text { Bluish grey, compact } \\
\text { sandy/silty diamict }\end{array}$ & Lodgement till & $\begin{array}{l}\text { Early or Middle } \\
\text { Weichselian } \\
\end{array}$ & \begin{tabular}{|l|} 
N7345.9 I2562.2 \\
M21, Vammavaara \\
\end{tabular} \\
\hline $\begin{array}{l}\text { Saarenkylä } \\
\text { Gytja }\end{array}$ & & $2-3 m$ & $\begin{array}{l}\text { Organic gytja, silt } \\
\text { and sand }\end{array}$ & $\begin{array}{l}\text { Lacustrine or } \\
\text { marine deposit }\end{array}$ & $\begin{array}{l}\text { Eem Interglacial } \\
\text { or Early } \\
\text { Weichselian } \\
\end{array}$ & $\begin{array}{l}\text { N7382.5 I3447.6 } \\
\text { Saarenkylä } \\
\text { (Sutinen 1992) }\end{array}$ \\
\hline \begin{tabular}{|l} 
Saarenkylä \\
Till \\
Formation \\
\end{tabular} & & $>1 \mathrm{~m}$ & $\begin{array}{l}\text { Grey, compact } \\
\text { sandy diamict }\end{array}$ & Lodgement till & Saalian & $\begin{array}{l}\text { N7382.5 I3447.6 } \\
\text { Saarenkylä } \\
\text { (Sutinen 1992) }\end{array}$ \\
\hline
\end{tabular}

Table 2. The correlation of Quaternary lithostratigraphy with earlier studies in the area of southern Finnish Lapland.

\begin{tabular}{|c|c|c|c|c|c|c|}
\hline \multirow[t]{2}{*}{ Formation } & \multirow[t]{2}{*}{ Member } & \multicolumn{5}{|c|}{ Correlation } \\
\hline & & $\begin{array}{l}\text { Korpela } \\
(1969)\end{array}$ & $\begin{array}{l}\text { Aario \& Forsström } \\
(1979)\end{array}$ & Mäkinen (1979) & Hirvas (1991) & Sutinen (1992) \\
\hline \begin{tabular}{|l|} 
Suolijoki \\
Formation \\
\end{tabular} & & & & Shore deposit & & \\
\hline \multirow{3}{*}{$\begin{array}{l}\text { Tervola Till } \\
\text { Formation }\end{array}$} & $\begin{array}{l}\text { Korttelivaara } \\
\text { Till Member } \\
\end{array}$ & \multirow{3}{*}{ Upper Till } & \multirow{3}{*}{ Ranua Till } & \multirow{3}{*}{ Upper Till Bed } & Surficial Till S & \multirow{3}{*}{ Rovaniemi Till } \\
\hline & \begin{tabular}{|l} 
Petäjävaara \\
Till Member
\end{tabular} & & & & & \\
\hline & \begin{tabular}{|l} 
Vammavaara \\
Till Member \\
\end{tabular} & & & & Till Bed II & \\
\hline $\begin{array}{l}\text { Sihtuuna } \\
\text { Sands }\end{array}$ & & $\begin{array}{l}\text { Peräpohjola } \\
\text { Interstadial }\end{array}$ & & \begin{tabular}{|l} 
Kauvonkangas \\
Interstadial
\end{tabular} & $\begin{array}{l}\text { Maaselkä } \\
\text { Interstadial }\end{array}$ & $\begin{array}{l}\text { Katosharju } \\
\text { Interstadial }\end{array}$ \\
\hline \begin{tabular}{|l|} 
Kemijoki Till \\
Formation \\
\end{tabular} & & Lower Till & Pudasjärvi Till & Middle Till Bed & Till Bed III & Kemijoki Till \\
\hline $\begin{array}{l}\text { Saarenkylä } \\
\text { Gytja }\end{array}$ & & & & $\begin{array}{l}\text { Lower glaciofluvial } \\
\text { deposit }\end{array}$ & & $\begin{array}{l}\text { Saarenkylä } \\
\text { Interglacial }\end{array}$ \\
\hline \begin{tabular}{|l} 
Saarenkylä Till \\
Formation
\end{tabular} & & & & Lower Till Bed & Till Bed IV & Saarenkylä Till \\
\hline
\end{tabular}




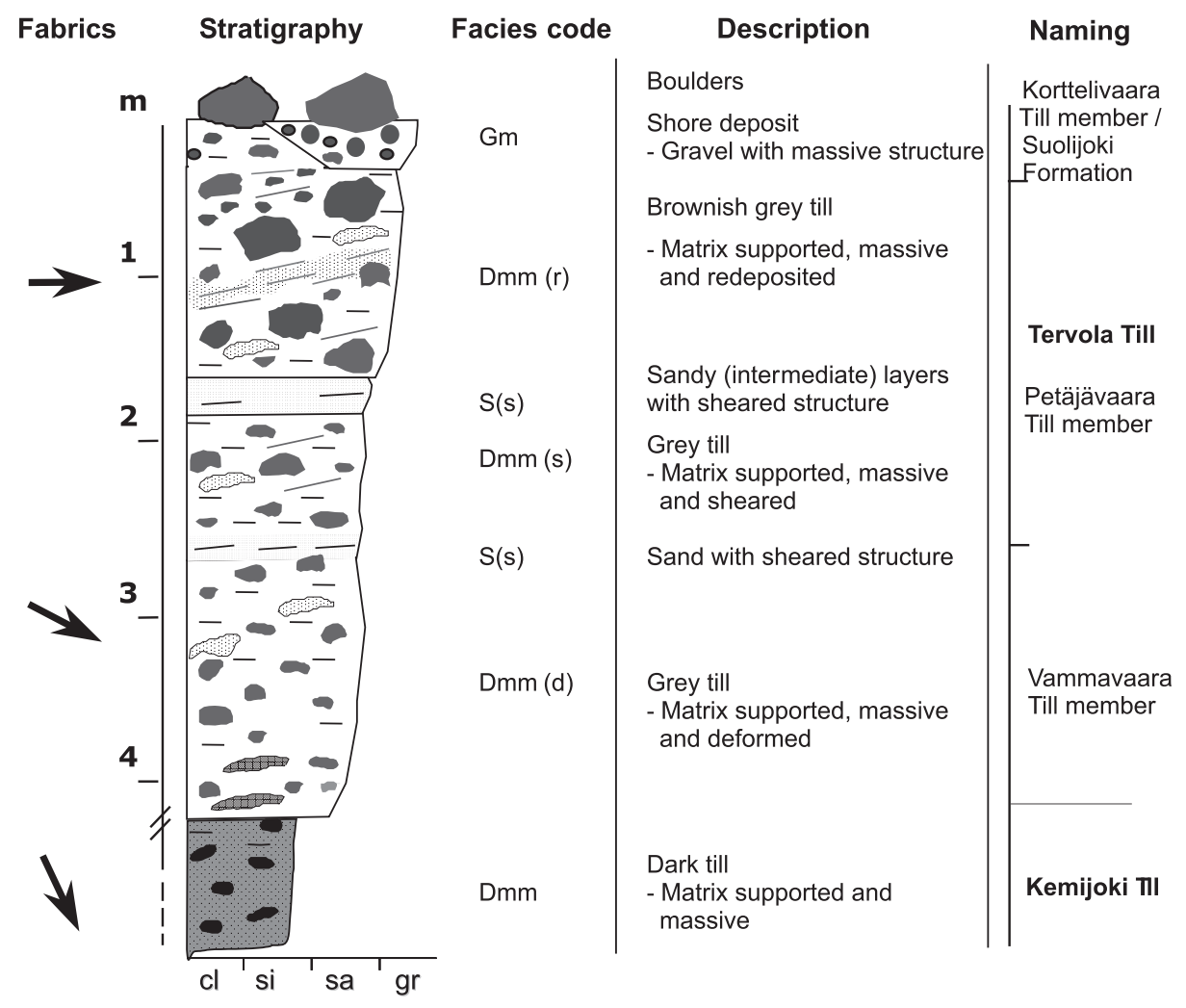

Fig. 25. Composition stratigraphic log of ribbed moraines in the Rovaniemi-Tervola area, southern Finnish Lapland, showing various lithofacies and their interpretation. Arrows depict mean glacial flow direction in different till units.

Till, existing only in the upper part of the ribbed moraine ridges (Fig. 25), has a characteristically rough (often gravelly) matrix, including large boulders and is composed of material that was transported only a very short distance. Fine-grained or sandy layers and lenses with shear structures are also typical. Stones and boulders are more angular than beneath and their rock types reflect the composition of underlying bedrock. Also, in the fine fractions of till local phenomena is characteristic, which is seen in till geochemistry and heavy mineralogy as for example, high gold and copper concentrations on a distal side of the mineralized bedrock (cf. Peuraniemi, 1982; Sarala et al., 1998; Sarala \& Rossi, 1998, 2000). The number of large boulders increases upward and the surface of ridges is strewn with them. For example, in the Sihtuuna moraine area the phenomenon is distinct, although all the properties described above are com- mon throughout the ribbed moraine area in southern Finnish Lapland.

The third uppermost till member, Korttelivaara Till, is very variable of its structures and composition. In places it has quite homogenous structure and rock fragments represents local bedrock composition, but commonly it consists great amounts of stratified sediments as lenses and layers, also convolution and shear structures are common reflecting deposition as melt-out or flow tills. Relative long transport of rock material can also be typical for this till. One reason for great variation is that at the end of deglaciation, the presence of the water body of Ancylus Lake caused the till material released from the melting ice to be deposited as waterlain till or as washed sediments above earlier deposits. Also, some stratified sands and fine-grained sediments were deposited. 
As the water level went down due to isostatic uplift and later, as the channel to the North Sea was opened in the south, shore plains with washed boulder fields formed on the slope of hills and the layers of massive shore deposits or stratified sediments called as the Suolijoki Formation were deposited on a lower level. For that reason the surface of morainic landscape was commonly covered with washed shore deposits in south-western Finnish Lapland.

\section{The relation of glacial morphology to glacial dynamics}

Glacial erosion was strong in the area of active ice lobes during the last glaciations in southern Finnish Lapland. In large areas, older glaciogenic deposits and bedrock surface were intensively worn out and the thickness of overburden is low. Variable bedrock composition influenced glacial erosion in relatively wide areas, resulting in the low bedrock relief. Only higher hill areas composed mainly of quartzites, formed obstacles to glacial flow and river basins, large fracture zones and other topographic depressions were reservations for sedimentary sequences. Glacial morphology older than the Late Weichselian was also protected from glacial erosion under the frozen bottom of glacier's core.

According to striae, till stratigraphy and the orientation of moraine landforms, only three glacial phases are identified in the area. Although, the observations of the Saarenkylä Till are minor, the southwestern stone fabrics indicate a more southern location of the ice divide during the deposition compared with the position of divide zones during the later glacial phases (Fig. 24).

The Kemijoki Till represents the glacial phase when glaciers reached the level of southern Finnish Lapland and the older drumlin fields were formed with a north-northwest orientation. Older drumlin field with drumlins large in scale was preserved only under cold-bed conditions and later, beneath the Ranua interlobate in the area of Kemi and Ranua during the last deglaciation. In the areas of active ice lobes, the Kemijoki Till was preserved in river basins and under a shelter of bedrock elevations. A series of marginal formations from the town of Pudasjärvi to the northwest indicates a slow retreating rate and maybe oscillations during that deglaciation.

In this study, two observations have been made of the older, till-covered stratified sediments. At the Korttelivaara site, in the middle of a moraine hill, sand deposits (in Fig. 22) are part of the northeast-southwest oriented stratified formation of which Sarala (1997) has interpreted to be a part of marginal formation that has survived under later glacial advance and erosion between the bedrock hills. At the Sihtuuna site, the deepest parts of the minor ribbed moraine ridges are also composed of the Sihtuuna Sands. The sands can be followed through the central ridge area in southwest-northeast direction. Planar bedding and smallscale cross lamination gives an impression of a restful meltwater stream discharging into the deep waterbody. This formation is interpreted as a glaciofluvial delta, which was deposited during the short standstill of the glacier margin in its retreat stage (Fig. 26). Lunkka \& Gibbard (1996) have described a similar deltaic formation in southern Finland. Meltwaters flowed enor supraglacially rather than subglacially because the melt-water channels are not known to exist along the northwestern side of the Sihtuuna moraines. However, that area is poorly examined and it is possible that the till-covered eskers may exist.

Before the third glacial phase, ice-free, interstadial phase existed in southern Finnish Lapland. Climate favored peat and birch forest to grow although mean temperature was not high. Periglacial structures like ice-wedge casts and involution marks in old glaciofluvial or marginal formations (cf. Mäkinen, 1999) and in the surficial parts of the Kemijoki Till are the remnants of the cold phase at the end of interstadial. Since the formation of those structures requires a mean temperature of less than $-5^{\circ} \mathrm{C}$ (cf. Lagerbäck, 1988b), the ground was presumably totally frozen during the growth of next glacier.

The third glacial phase has had a major influence on formation of the present glacial morphology. The central areas of the glacier were cold-based and stagnant, preserving the old morphology. Marginal parts, 


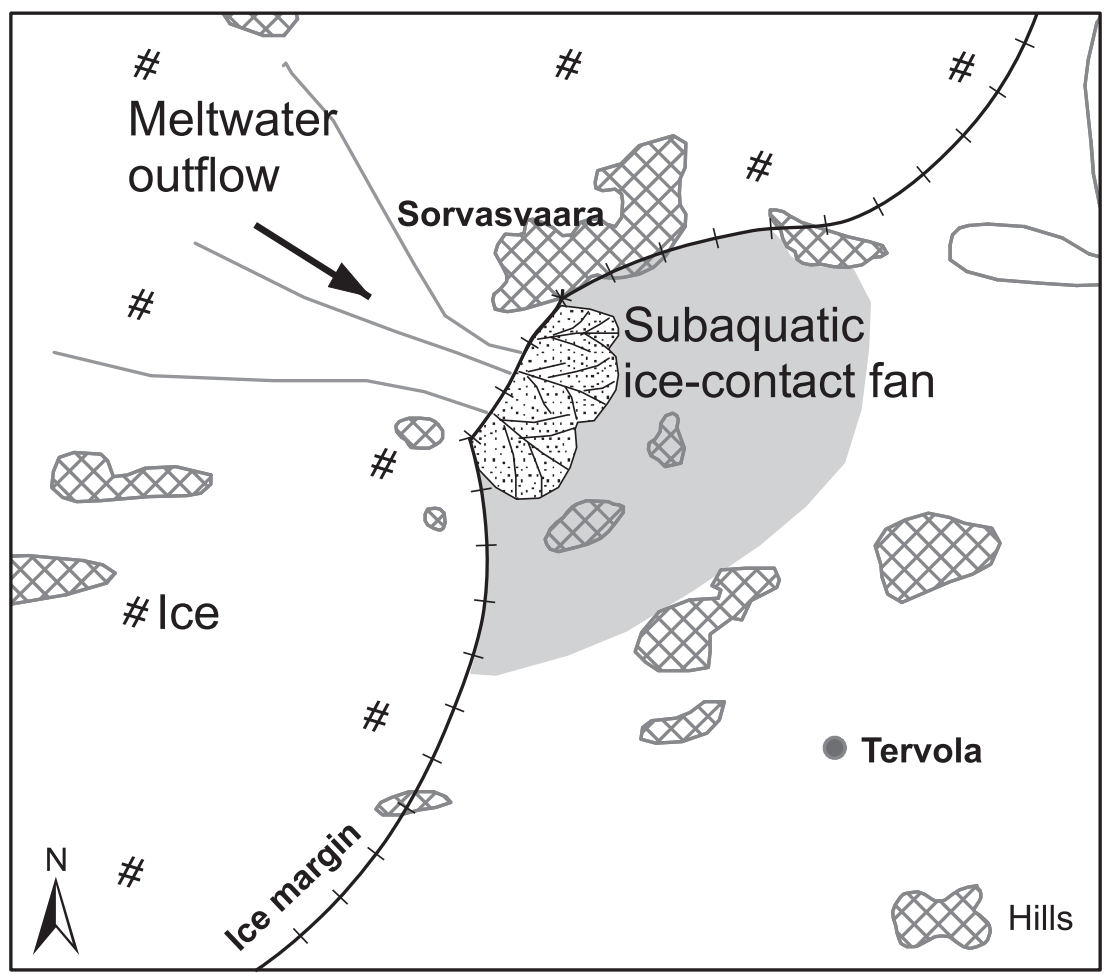

Fig. 26. Simplified model of deposition of stratified sediments as a subaquatic ice-contact fan in the middle of Sihtuuna area. Sands with planar bedding and small-scale cross lamination are largely occurring in a lower part of the Sihtuuna moraine ridges.

especially during deglaciation were divided into the active lobes and passive interlobate areas (Fig. 6; e.g. Aario \& Forsström, 1979; Punkari, 1984). Stream velocity in the active lobes was high, at least during the late stages of deglaciation as estimated by Kleman et al. (1997) and Arnold \& Sharp (2002). The moraine assemblage from the transversal ridges to streamlined formations developed. Particularly in the areas of the Kuusamo and Oulu ice lobes (in Fig. 6), an association of ribbed moraine-drumlin-fluting morphologies dominates (cf. Aario 1977b, 1990). The same type of formation assemblage also exists in the archipelago in western Finland (Breilin et al., 2004).

During deglaciation, when the glacial margin was in the area of Karelia, Russia, ice lobes from Kuusamo and Oulu initially flowed parallel to each other from the west to the east (cf. Aario \& Forsström, 1979). As the melting phase progressed to the level of eastern Finland, the ice lobes began to separate. An interlobate zone existed from the village of Taivalkoski to- ward the west. The hill area surrounding Iso-Syöte (in Fig. 4), on the northeastern side of the town of Pudasjärvi was a natural divide for ice lobes. After separation, the Oulu ice lobe continued to flow from west to east, but the Kuusamo ice lobe shifted the interlobate area and the flow direction was from the westnorthwest to the southeast. Later, the flow direction of the Kuusamo ice lobe developed so that in the area of Kemijärvi-Rovaniemi-Tervola it was from west to east and in western Finnish Lapland from the northwest. This development can be also followed in stone fabrics and esker directions. Some divergent fabrics and striae observations have been done in the study area, but they are mostly due to local variation of glacial flow direction, for example near the higher hills and valley basins.

The Ranua interlobate area between the active ice lobes was cold-based, stagnant and non-eroding. Sutinen (1992) presented many western fabrics at surficial parts of older drumlins, which are indicative 
of weak glacial flow at the latest phase of deglaciation. Also, some west-east oriented, streamlined features were found superimposed on drumlins and in places, the center of drumlins was distended on the eastern side. The movement and activity of the ice stream was insignificant to form its own morphology. Presumably, this interlobate area stayed passive to the end of deglaciation and just melted in place. The northern edge toward the Kuusamo ice lobe is sharp, which is clearly seen for example in the Portimojärvi area (in Fig. 4) where the younger ribbed moraine field cuts the older drumlin field. Only a few unique, northwest-southeast oriented drumlins or drumlinoids can be distinguished within the area of the ribbed moraines. On the southern edge, the interlobate complex continued through Taivalkoski and Pudasjärvi to the western coast.

\section{Ice sheet and landform develop- ment and the age of glacial phases}

As pointed out earlier, the organic inter-till layers have had a significant role when creating glacial chronology in northern Finland. But as reliable dating methods were not in use, the chronology was tied only to till stratigraphy and pollen composition (e.g. Hirvas, 1991; Helmens et al., 2000). Instead, the use of glacial landforms and their associations as reconstructing glaciers behavior and ice sheet development has been minor (Sutinen, 1992). For that reason the glacial morphology and glacial dynamics were put together with till stratigraphy and present chronological data to re-examine time-transgressive glacial history in southern Finnish Lapland and surrounding areas.

The hypothesis when modeling ice sheet and landform development was that the mass of glaciers was many times smaller during the Early Weichselian than later as latest estimations made by Siegert et al. (2001), Arnold et al. (2002), Fabel et al. (2002), Fredin (2002), Näslund et al. (2003) and Forsström (2004) point out. Fennoscandia was almost ice-free or only a little glaciated in mountain areas while greater glaciers existed elsewhere. For example, according to
Svendsen et al. (1999) and Mangerud et al. (2001), areas of northern Russia and the Barents Sea were largely ice-covered during oxygen isotope stage (OIS) 5b (95-85 ka). During the Middle and Late Weichselian glaciations, the mass and extent of glaciers in those areas decreased but increased in the Fennoscandia area over time (Svendsen et al., 2004). These estimations are important and prove that under different circumstances the mass, extent and behavior of glaciers around the Northern Hemisphere can vary significantly.

Another hypothesis was that even if the origin of organic, inter-till deposits was presented to be redeposited interglacial (Eemian) sediments (e.g. Forsström, 1991, 1995; Forsström \& Punkari, 1997), the contrary view for that is several observations of organic intermediate layers stratigraphically in a logical position in till sequences and sample profiles (Hirvas et al., 1977; Hirvas, 1991; Saarnisto et al., 1999; Helmens et al., 2000). It is also worth noting that organic layers are usually very thin and probably represent only the deepest and oldest part of the deposits while the upper parts were eroded away.

\section{I. Model I}

In the latest investigations (Helmens et al., 2000; Lunkka et al., 2004; Saarnisto \& Lunkka, 2004; Svendsen et al., 2004), the first Weichselian glaciation that reached the area of northern Finland was interpreted to occur in OIS 5b. In the first phase (Fig. 27a), the glacial margin advanced to southern Finnish Lapland, on the southern side of the town of $\mathrm{Pu}$ dasjärvi, and the northwest-southeast oriented drumlin field and a series of marginal formation were deposited as presented by Sutinen (1992). The drumlin field with same orientation can be followed as far as central Lapland, where unique forms or their relicts can be distinguished. The Peräpohjola Interstadial followed during the first interstadial at stage 5a (85$74 \mathrm{ka})$ and correlates with the Odderade Interstadial (cf. Nenonen, 1995; Lunkka et al. 2004). During the second phase (Fig. 27b), the Middle Weichselian glaciation advanced at least to southern Finland (cf. 

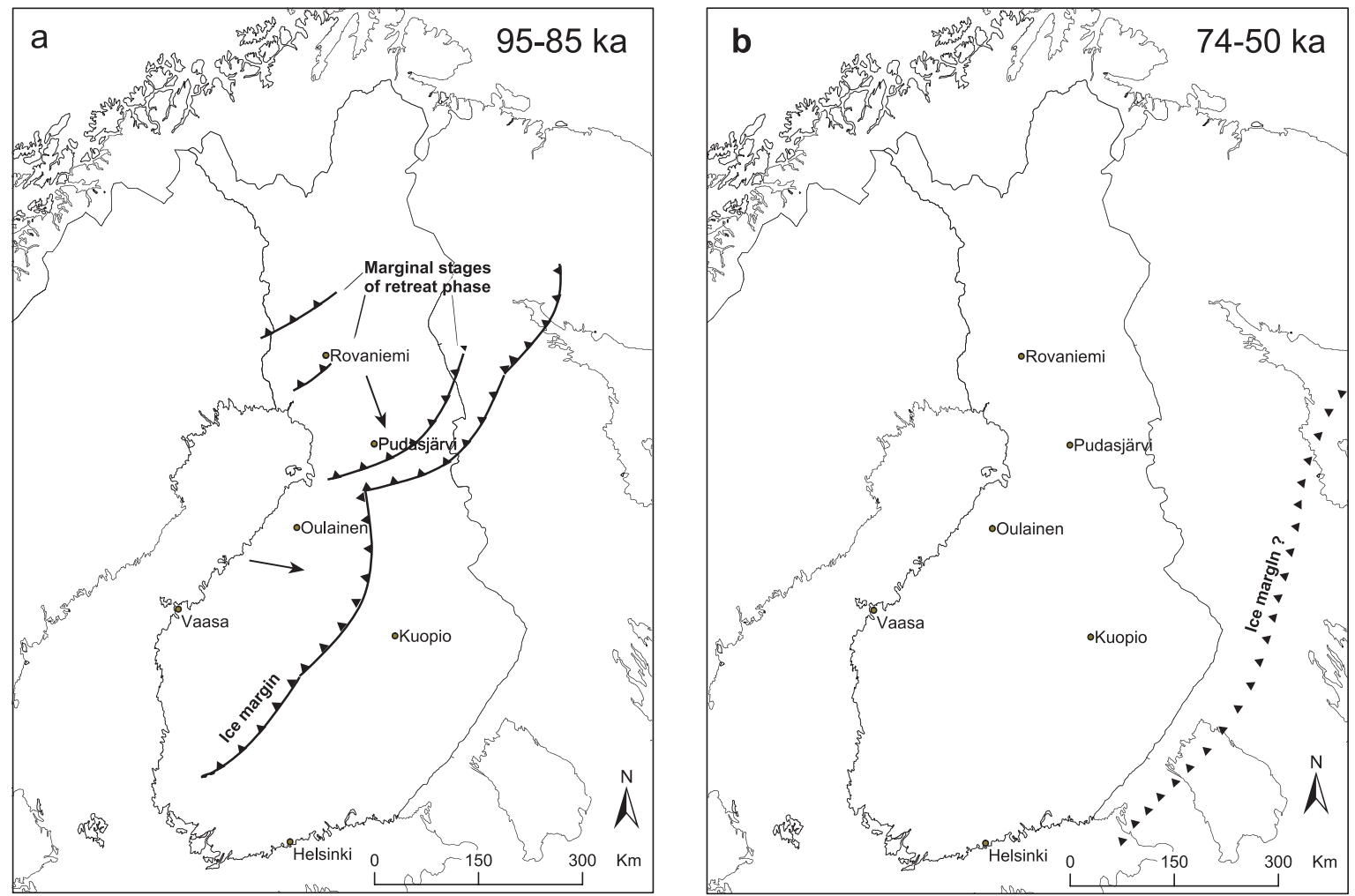

Fig. 27. Model I:The first interpretation of glacial morphological and stratigraphical development during the Weichselian in southern Finnish Lapland, a) Phase I, where the Early Weichselian glaciation advanced to the level of Oulainen and Pudasjärvi (cf. Lundqvist, 1992). Glacial flow directions of ice streams are depicted as arrows. The glaciation was followed by the Peräpohjola Interstadial, b) Phase II, where the Middle Weichselian glaciation covered the whole of Finland and might be lasted to the end of Late Weichselian without a break.

Svendsen et al., 2004), but because evidence of the second interstadial is missing, this glaciation has continued to the end of the Late Weichselian without a break. The association of ribbed moraines, drumlins and flutings was thus formed during the last deglaciation.

During the earliest sub-stages of the Weichselian (e.g. $5 \mathrm{c}$ and $5 \mathrm{~d}$ ), the ice sheet probably did not cover northern Finland (cf. Svendsen et al., 2004), so substages $5 \mathrm{~b}$ and $5 \mathrm{a}$ may be the oldest phases when the Kemijoki Till and the following interstadial peat deposits could have been deposited. This is not in conflict with the observations made from southern Finnish Lapland. However, the observations of dark grey till in central and western Finland (may be correlative with the Kemijoki Till in southern Lapland) are problematic, because the till was interpreted have been de- posited during the Early Weichselian sub-stage before interstadial deposits (Iisalo, 1992, 2003; Nenonen, 1992, 1995). If this is true, the first Weichselian glaciation must have reached much farther than the $\mathrm{Pu}$ dasjärvi area or there may have been separate, western ice streams in the area of western Finland (cf. Lundqvist, 1992) (Fig. 27a).

\subsection{Model 2}

Another interpretation can explain the chronology well, at least in the case of northern Finland. If the Early Weichselian glaciation (85-95 ka) was many times smaller than earlier thought, the glacier covered only the northernmost area of Finland (Fig. 28a), but not southern Finnish Lapland (cf. Siegert et al., 2001; Arnold et al., 2002; Fabel et al., 2002; Fredin, 2002; Näs- 

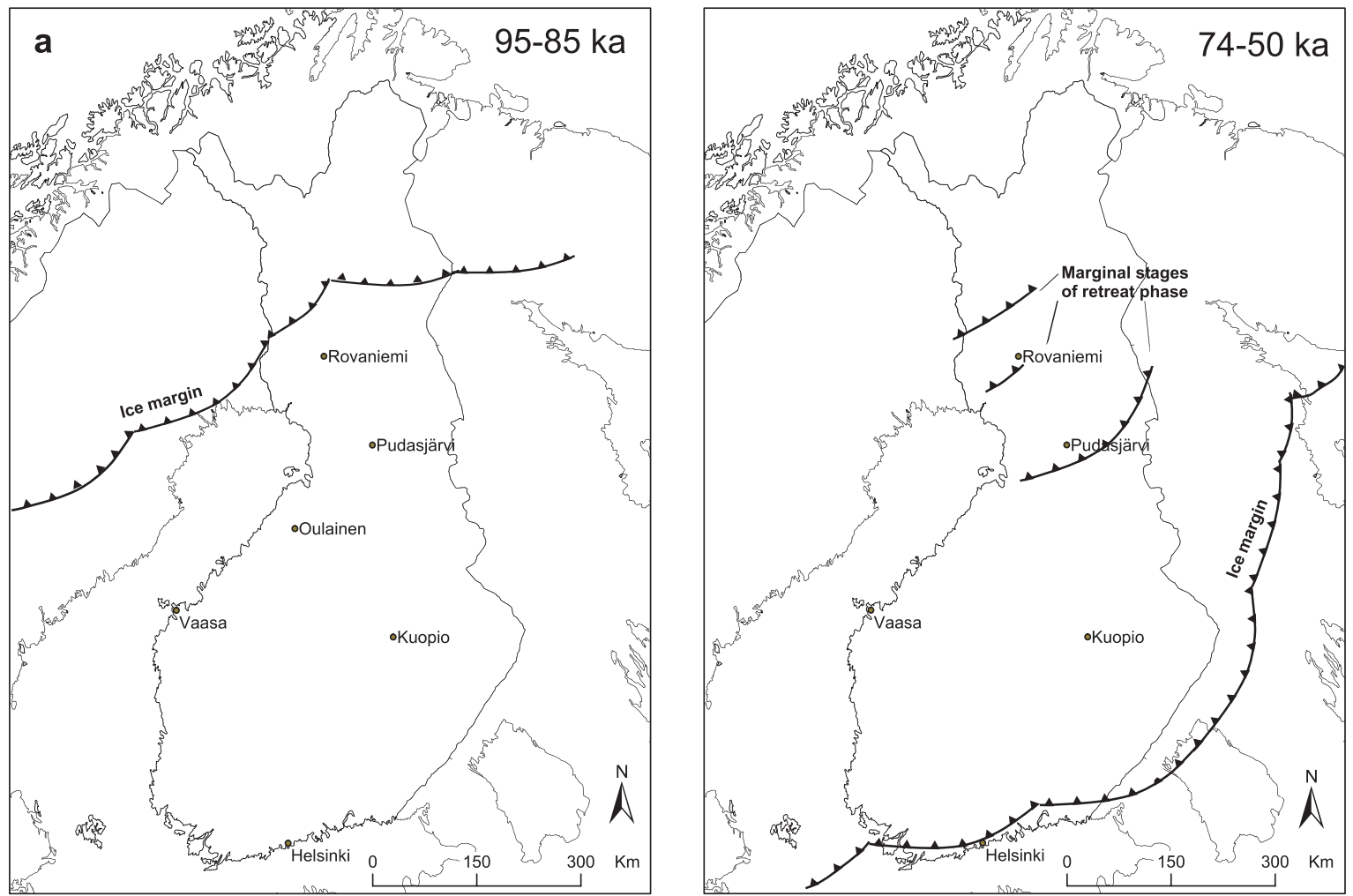

Fig. 28. Model 2: The second interpretation of glacial morphological and stratigraphical development during the Weichselian in southern Finnish Lapland, a) Phase I, where the Early Weichselian glaciation covered only the area of central Lapland and southern Finnish Lapland stayed ice-free, b) Phase II, where the Middle Weichselian glaciation initially covered southern Finnish Lapland advancing at least to the level of southern Finland (cf. Svendsen et al., 2004). Marginal formations in northern Finland were formed during the first deglaciation. The interstadial followed during oxygen isotope stage 3 before the Late Weichselian glaciation.

lund et al., 2003). This is supported by the observations from middle and eastern Finnish Lapland where three Weichselian till beds can only be found in the same sections (Sutinen, 1992 and reference within; Johansson, 1995; Helmens et al., 2000). It was not until the Middle Weichselian (OIS 4), when the glacier initially advanced to southern Finnish Lapland and might have covered the whole of Finland, too (Fig. 28b). The till that was deposited during that glaciation was the Kemijoki Till in southern Lapland and northwestsoutheast drumlin field was also formed.

The ice-free period would have lasted 40 000-50 000 years after the Eemian interglacial if not counting northernmost Finnish Lapland. This time scale should be enough for the isostatic uplift to reach a normal, balanced stage after the Saalian glaciation and as a result, the bottom of the Bothnian Sea could have been at a higher level, maybe 90-100 m higher than present (cf. Nenonen, 1995). That is why the hydrography throughout the central and northern Finland has been different compared with the Holocene period. Afterwards, a lot of the sulphide rich, fine-grained sediments were easily eroded away during the subsequent glaciation. This explains the high concentration of sulphur and the large amount of clays and organic matter in the Kemijoki Till.

The Middle Weichselian glaciation lasted only 15 000-20 000 years and a series of marginal formations from Pudasjärvi towards to northwest formed during the melting phase of that ice sheet. The ice-free period began about 50-55 ka ago and may have lasted up to 30-25 ka ago as Lunkka et al. (2001) and Svend- 


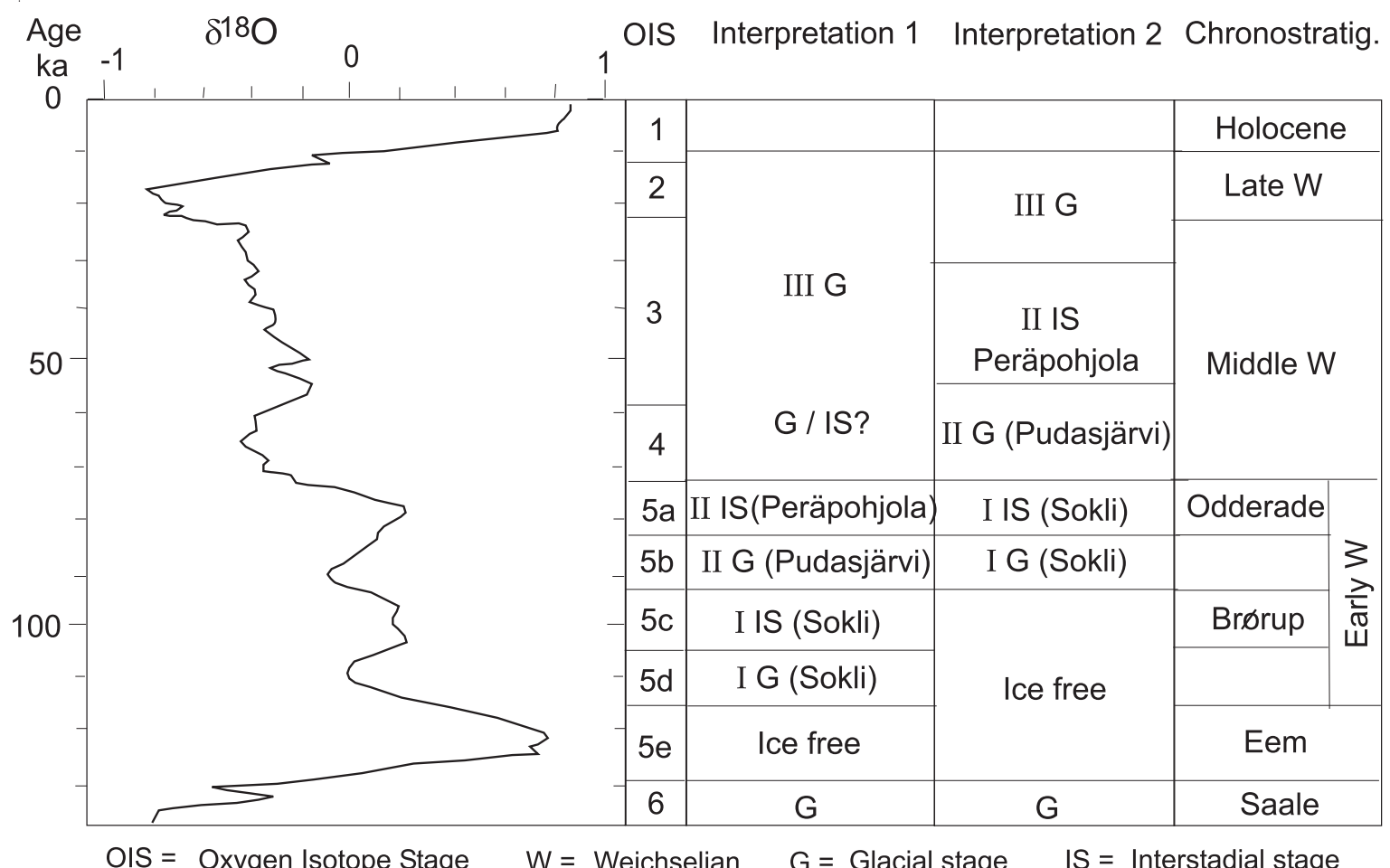

Fig. 29. Summary and correlation of the interpretations of glacial morphological and stratigraphical development during the Weichselian. The main places and events of southern and central Finnish Lapland (marginal stages of retreat phase from Pudasjärvi towards the north (cf. Sutinen, 1992), Peräpohjola Interstadial (Korpela, 1969) and the glacial/ interstadial phases observed in Sokli (Helmens et al., 2000)) used in the correlation have also been presented.

sen et al. (2004) have estimated. Some TL and OSL dating of the samples taken from the same sections as the ${ }^{14} \mathrm{C}$ samples (of age $40-55 \mathrm{ka}$ ) have given somewhat similar age estimates (Punning \& Raukas, 1983; Hütt et al., 1984; Nenonen, 1995; cf. also Forsström \& Punkari, 1997). The latest TL $(37 \pm 0.5 \mathrm{ka}-55$ ka) and OSL (41 $\pm 2 \mathrm{ka}-66 \pm 5 \mathrm{ka})$ ages (Mäkinen, pers. commun. 2005) also support that phenomenon. Furthermore, the age determinations of mammoth and reindeer bones from southern Finland and even from southern Finnish Lapland have proven that Finland might have been ice-free even at the end of Middle Weichselian (Ukkonen et al., 1999; Lunkka et al., 2001; Lôugas et al., 2002). According to this evidence, the last glacial advance was estimated to have begun about 25-30 ka ago in Finnish Lapland (Lunkka et al., 2004; Svendsen et al., 2004).

The thought of an ice-free stage during that time is unavoidable given the re-examination of ${ }^{14} \mathrm{C}$ ages clustering around $40-55 \mathrm{ka}$, even if there is a great uncertainty among radiocarbon ages older than 40 ka (cf. Nenonen, 1995 and the references within; Kitagawa \& van der Plicht, 1998). However, in the latest studies the accuracy of radiocarbon method has been proved to be good in the sections older than 50000 years BP (Voelker et al., 2000; Hughen et al., 2004; Fairbanks et al., 2005). Model 2 gives a possibility for these ages to be correct (Fig. 29, interpretation 2). If the lowermost parts of the interstadial deposits are only remaining, ${ }^{14} \mathrm{C}$ age estimations over $40 \mathrm{ka}$ could be correlated with the beginning of the Middle Weichselian warm stage and correspond with the ages of the mammoth and reindeer bones.

In Model 2, the Kemijoki Till observed as far as southern Finland was deposited during the Middle Weichselian glaciation before the interstadial. Variation of stone fabrics in this till bed is followed by the separation of the ice margin by the ice lobes in the 
same way as during the latest deglaciation. Till-covered, marginal formations in Pudasjärvi and to the northwest were deposited during the melting stage of the Middle Weichselian glaciation. Marginal formations in southern Finland might have eroded away during the Late Weichselian glacial advance or they were not observed because of till cover or their occurrence in relation to younger, marginal formations. Furthermore, if southern Finland was glaciated for the first time during the Middle Weichselian, organic material from the Early Weichselian (occurring as intermediate layers between till units in Ostrobothnia) is probably a result of redeposition.

Model 2 can be also correlated with observations made from northern Sweden (e.g. Lagerbäck, 1988a, b; Lagerbäck \& Robertsson, 1988; Lundqvist, 1992), where two interstadials were interpreted. However, as Robertsson \& García Ambrosiani (1988) and García Ambrosiani \& Robertsson (1992) have presented, only one inter-till (interstadial) bed interpreted to be of Early or Middle Weichselian age existed in the coastal area of eastern Sweden. If compared to the latest estimations of ice sheet extents during the Weichselian, the Early Weichselian glaciation was also small in Sweden and probably existed only in the northernmost or western areas. Thus, the glacial history of eastern Sweden can also be correlative with the model presented here. As well, the Tärendö Interstadial presented by Lagerbäck \& Robertsson (1988) in northeastern Norrbotten might be comparable with the Middle Weichselian Interstadial during OIS 3.

\section{Conclusions}

The area of southern Finnish Lapland is situated close to the central areas of the former glaciations. Quaternary lithostratigraphy of the area is proposed to call as the Peräpohja Group which is composed of three till beds and two inter-till, stratified minerogenic sediment layers containing in many places organic material. The Saarenkylä Till dates back to the Saalian glaciation and the lower organic sediment deposit named as Saarenkylä Gytja represents the Eemian interglacial. The other till beds, the Kemijoki Till and the Tervola Till with till members of the Vammavaara Till, Petäjävaara Till and Korttelivaara Till are deposits of the Weichselian glaciation. The second organic inter-till deposit in between the Kemijoki Till and the Tervola Till, indicate an ice-free phase called as the Peräpohjola Interstadial from the Weichselian glaciation. The Sihtuuna Sands within the Sihtuuna moraine ridges can be compared with that interstadial phase. The gravelly and sandy shore deposits at the surficial parts of moraine surface represent proglacial Ancylus Lake stage and are named the Suolijoki Formation.

Glacial morphology depicts two active, Weichselian glacial advances with good indications of glacial flow directions. An older glacial phase with northwestsoutheast orientation is seen as a drumlin field that was preserved under the cold-based, Ranua interlobate area. The ribbed moraine-drumlin-fluting assemblage correlates with the Late Weichselian glaciation and represents a younger glacial phase indicating ice lobe flow patterns and dynamics during deglaciation.

According to the development of the Weichselian glacial morphology and stratigraphy and correlation with present available chronological data, two models have been constructed:

1. In the first model, the Kemijoki Till and the northwest-southeast oriented drumlin field were deposited during the initial glacial phase occurred during the Early Weichselian. The Peräpohjola Till and the west-east oriented ribbed moraine-drumlin-fluting assemblage represent the second glacial phase from the beginning of the Middle Weichselian to the end of the Late Weichselian. The interstadial phase occurred at the end of the Early Weichselian.

2. In the second model, the first Weichselian glacial advance was quite modest in extent and covered only the area of northern Finland. It was not until the Middle Weichselian when the glacier reached southern Finnish Lapland for the first time. If so, the first warmer stage (interstadial) was at the end of Middle Weichselian, meaning that TL and OSL ages and most of the ${ }^{14} \mathrm{C}$ age estimations about $40 \mathrm{ka}$ and somewhat older may be correct. Finally, the interstadial was followed by the relatively short but very intensive and large Late Weichselian glaciation. 


\section{Acknowledgements}

This research was done as a joint project between the GTK and the University of Oulu. The Foundation of Research of Natural Resources in Finland also funded works. Constructive criticism and comments given by Prof. Vesa Peuraniemi, Prof. Matti Saarnisto, Dr. Clas Hättestrand, Dr. Peter Johansson, M.Sc. Seppo Rossi and three anonymous referees improved the manuscript. Mrs. Carrie Turunen checked the English of manuscript.

\section{References}

Aario, R., 1977a. Classification and terminology of morainic landforms in Finland. Boreas 6, 87-100.

Aario, R., 1977b. Associations of flutings, drumlins, hummocks and transverse ridges. GeoJournal 1: 6, 65-72.

Aario, R., (ed.) 1990. Glacial heritage of Northern Finland; an excursion guide. Nordia tiedonantoja, Sarja A: $1,96 \mathrm{p}$.

Aario, R. \& Forsström, L., 1979. Glacial stratigraphy of Koillismaa and North Kainuu, Finland. Fennia 157: 2, $1-49$.

Aario, R. \& Peuraniemi, V., 1992. Glacial dispersal of till constituents in morainic landforms of different types. In: Aario, R. \& Heikkinen, O. (eds.) Proceedings of Third International Drumlin Symposium, Geomorphology 6, 9-25.

Aario, R., Peuraniemi, V. \& Sarala, P., 1995. Sihtuuna moraine of Tervola, southern Lapland. In: Klostermann, J. (ed.) International Union for Quaternary Research XIV International Congress, August 3-10, 1995, Freie Universität Berlin, Abstracts, Terra Nostra 2/95.

Aario, R., Peuraniemi, V. \& Sarala, P., 1997. The Sihtuuna moraine at Tervola, southern Lapland. Sedimentary Geology 111, 313-327.

Arnold, N., van Andel, T. \& Valen, V., 2002. Extent and Dynamics of the Scandinavian Ice Sheet during Oxygen Isotope Stage 3 (65,000-25,000 yr B.P.). Quaternary Research 57, 38-48.

Arnold, N. \& Sharp, M., 2002. Flow variability in the Scandinavian ice sheet: modelling the coupling between ice sheet flow and hydrology. Quaternary Science Reviews 21, 485-502.

Ber, A. \& Kujansuu, R., 1974. The till profile of Rovaniemi, Finland. Geografia 10, 193-201.

Bouchard, M., 1989. Subglacial landforms and deposits in central and northern Quebec, Canada, with emphasis on Rogen moraines. Sedimentary Geology 62, 293-308.

Boulton, G.S., Dongelmans, P., Punkari, M. \& Broadgate, M., 2001. Palaeoglaciology of an ice sheet through a glacial cycle: the European ice sheet through the Weichselian. Quaternary Science Reviews 20, 591-625.

Breilin, O., Kotilainen, A., Nenonen, K., Virransalo, P., Oja- lainen, J. \& Stén, C.-G., 2004. Geology of the Kvarken Archipelago. Espoo, Geological Survey of Finland, 47 p.

Clark, C., 1997. Reconstructing the evolutionary dynamics of former ice sheets using multi-temporal evidence, remote sensing and GIS. Quaternary Science Reviews 16, 1067-1092.

Clark, C., 1999. Glaciodynamic context of subglacial bedform generation and preservation. Annals of Glaciology $28,23-32$.

Donner, J., Korpela, K. \& Tynni, R., 1986. Veiksel-jäkauden ajoitus Suomessa. Terra 98, 240-247.

Evans, D. \& Rea, B., 1999. Geomorphology and sedimentology of surging glaciers: a land-systems approach. Annals of Glaciology 28, 75-82.

Fabel, D., Stroeven, A., Harbor, J., Kleman, J., Elmore, D. \& Fink, D., 2002. Landscape preservation under Fennoscandian ice sheets determined from in situ produced ${ }^{10} \mathrm{Be}$ and ${ }^{26} \mathrm{Al}$. Earth and Planetary Science Letters 201, 397-406.

Fairbanks, R.G, Mortlock, R.A., Chiu, T.-C., Cao, L., Kaplan, A., Guilderson, T.P., Fairbanks, T.W., Bloom, A.L., Grootes, P.M. \& Nadeau, M.-J., 2005. Radiocarbon calibration curve spanning 0 to 50,000 years $\mathrm{BP}$ based on paired ${ }^{230} \mathrm{Th} /{ }^{234} \mathrm{U} /{ }^{238} \mathrm{U}$ and ${ }^{14} \mathrm{C}$ dates on pristine corals. Quaternary Science Reviews 24, 1781-1796.

Forsström, L., 1991. The younger Dryas cold event - a consequence of a pulsed mechanism in ice sheet melting? Res Terrae A, No. 8, 9 p.

Forsström, L., 1995. The last glacial cycle (Weichselian) at the center of the Fennoscandian glaciated area, evidence from Finland. Res Terrae A, No. 11, 34 p.

Forsström, L. \& Punkari, M., 1997. Initiation of the last glaciation in northern Europe. Quaternary Science Reviews 16, 1197-1215.

Forsström, P.-L., 2004. Simulation of the Eurasian ice sheet dynamics during the last glaciation. In: Mansfeld, J. (ed.) The 26th Nordic Geological Winter Meeting, Uppsala, Sweden. Abstract volume. GFF 126:1, p. 116.

Fredin, O., 2002. Glacial inception and Quaternary mountain glaciations in Fennoscandia. Quaternary International 95-96, 99-112.

García Ambrosiani, K. \& Robertsson, A.-M., 1992. Early Weichselian interstadial sediments at Härnösand, Sweden. Boreas 21, 305-317.

Hart, J., 1999. Identifying fast ice flow from landform assemblages in the geological record: a discussion. Annals of Glaciology 28, 59-66.

Helmens, K.F., Räsänen, M.E., Johansson, P.W., Jungner, H. \& Korjonen, K., 2000. The Last Interglacial-Glacial cycle in NE Fennoscandia: a nearly continuous record from Sokli (Finnish Lapland). Quaternary Science Reviews $19,1605-1623$.

Hirvas, H., 1991. Pleistocene stratigraphy of Finnish Lapland. Geological Survey of Finland, Bulletin 354, 123 p.

Hirvas, H., Alftan, A., Pulkkinen, E., Puranen, R. \& Tynni, R., 1977. Raportti malminetsintää palvelevasta maape- 
rätutkimuksesta Pohjois-Suomessa vuosina 1972-1976. Summary: A report on glacial drift investigations for ore prospecting purposes in northern Finland 19721976. Geological Survey of Finland, Report of Investigation $19,54 \mathrm{p}$.

Hirvas, H. \& Nenonen, K., 1987. The till stratigraphy of Finland. In: Kujansuu, R. \& Saarnisto, M. (eds.) INQUA till symposium, Finland 1985. Geological Survey of Finland, Special Paper 3, 49-63.

Hughen, K., Lehman, S., Southon, J., Overpeck, J., Marchal, O., Herring, C. \& Turnbull J., 2004. ${ }^{14} \mathrm{C}$ Activity and global carbon cycle changes over the past 50,000 years. Science 303, 202-207.

Hütt, G., Punning, J.M. \& Raukas, A., 1984. Application of the TL method to elaborate the geochronological scale of the late Pleistocene for the East European Plain. In: Mahaney, W.C. (ed.) Correlation of Quaternary chronologies. GeoBooks, United Kingdom, 47-55.

Hütt, G., Jungner, H., Kujansuu, R. \& Saarnisto, M., 1993. OSL and TL dating of buried podsols and overlying sands in Ostrobothnia, western Finland. Journal of Quaternary Science 8, 125-132.

Hättestrand, C., 1997. Ribbed moraines in Sweden - distribution pattern and paleoglaciological implications. Sedimentary Geology 111, 41-56.

Hättestrand, C. \& Kleman, J., 1999. Ribbed moraine formation. Quaternary Science Reviews 18, 43-61.

Iisalo, E., 1992. Observations on the stratigraphy of Weichselian tills and subtill eskers in Central Ostrobothnia, Finland. Geological Survey of Finland, Report of Investigation 112, $42 \mathrm{p}$.

Iisalo, E., 2003. Till stratigraphy and geochemical differences between till beds in western Finland. Geological Survey of Finland, Special Paper 34, 21-42.

Johansson, P., 1995. The deglaciation in the eastern part of the Weichselian ice divide in Finnish Lapland. Geological Survey of Finland, Bulletin 383, 72 p.

Johansson, P., 2005. Moreenipeitteiset jäätikköjokimuodostumat. In: Johansson, P. \& Kujansuu, R. (eds.) PohjoisSuomen maaperä: maaperäkarttojen 1:400 000 selitys. Summary: Quaternary deposits of Northern Finland explanation to the maps of Quaternary deposits 1:400 000. Geological Survey of Finland, Espoo, 99-105.

Jungner, H., 1987. Thermoluminescence dating of sediments from Oulainen and Vimpeli. Boreas 16, 231235.

Kitagawa, H. \& van der Plicht, J., 1998. Atmospheric radiocarbon calibration to 45,000 yr B.P.: Late glacial fluctuations and cosmogenic isotope production. Science 279, 1187-1190.

Kleman, J., 1994. Preservation of landforms under ice sheets and ice caps. Geomorphology 9, 19-32.

Kleman, J. \& Borgström, I., 1996. Reconstruction on palaeo-ice sheets: The use of geomorphological data. Earth Surface Processes and Landforms 21, 893-909.

Kleman, J., Hättestrand, C., Borgström, I. \& Stroeven, A.,
1997. Fennoscandian palaeoglaciology reconstructed using a glacial geological inversion model. Journal of Glaciology 43, 283-289.

Kleman, J., Marchant, D. \& Borgström, I., 2001. Geomorphic evidence for late glacial dynamics on southern Baffin Island and in outer Hudson Strait, Nunavut, Canada. Arctic, Antarctic, and Alpine Research 33, 249-257.

Korpela, K., 1969. Die Weichsel-Eiszeit und ihr Interstadial in Peräpohjola (nördliches Nordfinnland) im Licht von submoränen Sedimenten. Annales Academiae Scientiarum Fennicae A III: 99, 1-108.

Kujansuu, R., 1967. On the deglaciation of western Finnish Lapland. Bulletin de la Commission géologique de Finlande 232, 98 p.

Kujansuu, R., 1975. Marrasjärven interstadiaalinen harju Keski-Lapissa. Summary: Interstadial esker at Marrasjärvi, Finnish Lapland. Geologi 27, 45-50.

Kujansuu, R., 1976. Glaciogeological surveys for ore-prospecting purposes in northern Finland. In: Legget, R.F. (ed.) Glacial till. The Royal Society of Canada, Special publications 12, 225-239.

Kurimo, H., 1974. Virtaviivaiset muodot jään liikuntojen kuvastajina Posion-Kuusamon alueella. (Streamline features as indications of ice movements in the Posio-Kuusamo area, NE-Finland). Terra 86:2, 52-61.

Kurimo, H., 1982. Ice-lobe formation and function during the deglaciation in Finland and adjacent Soviet Karelia. Boreas 11, 59-78.

Lagerbäck, R., 1988a. The Veiki moraines in northern Sweden - widespread evidence of an Early Weichselian deglaciation. Boreas 17, 469-486.

Lagerbäck, R., 1988b. Periglacial phenomena in the wooded areas of Northern Sweden - relicts from the Tärendö Interstadial. Boreas 17, 487-499.

Lagerbäck, R. \& Robertsson, A.-M., 1988. Kettle holes stratigraphical archives for Weichselian geology and palaeoenvironment in northernmost Sweden. Boreas 17, 439-468.

Lôugas, L., Ukkonen, P. \& Jungner, H., 2002. Dating the extinction of European mammoths: new evidence from Estonia. Quaternary Science Reviews 21, 1347-1354.

Lundqvist, J., 1969. Problems of the so-called Rogen moraine. Sveriges Geologiska Undersökning C 648, 1-32.

Lundqvist, J., 1989. Rogen (ribbed) moraine - identification and possible origin. Sedimentary Geology 62, 281-292.

Lundqvist, J., 1992. Glacial stratigraphy in Sweden. In: Kauranne, K. (ed.) Glacial stratigraphy, engineering geology and earth construction. Geological Survey of Finland, Special Paper 15, 43-59.

Lunkka, J.P. \& Gibbard, P., 1996. Ice-marginal sedimentation and its implications for ice-lobe deglaciation patterns in the Baltic region: Pohjankangas, western Finland. Journal of Quaternary Science 11, 377-388.

Lunkka, J.P., Saarnisto, M., Gey, V., Deminov, I. \& Kiselova, V., 2001. Extent and age of the Last Glacial Maxi- 
mum in the southeastern sector of the Scandinavian Ice Sheet. Global and Planetary Change 31, 407-425.

Lunkka, J.P., Johansson, P., Saarnisto, M. \& Sallasmaa, O., 2004. Glaciation of Finland. In: Ehlers, J. \& Gibbard, P.L. (eds.) Quaternary Glaciations - Extent and Chronology. Elsevier, 93-100.

Mangerud, J., 1991. The Last Ice Age in Scandinavia. Striae $34,15-30$.

Mangerud, J., Astakhov, V.I., Murray, A. \& Svendsen, J.I., 2001. The chronology of a large ice-dammed lake and the Barents-Kara Ice Sheet advances, Northern Russia. Global and Planetary Change 31, 321-336.

Menzies, J. \& Shilts, W., 1996. Subglacial environments. In: Menzies, J. (ed.) Past Glacial Environments: Sediments, forms and techniques, (Glacial Environments: Volume 2). Butterwoth-Heinemann, 15-136.

Mäkinen, K., 1979. Interstadiaalinen turvekerrostuma Tervolan Kauvonkankaalla. Summary: An interstadial peat layer at Kauvonkangas, Finnish Lapland. Geologi 31, 82-87.

Mäkinen, K., 1985. On the till-covered glaciofluvial formations in Finnish Lapland. Striae 22, 33-40.

Mäkinen, K., 1999. Ice wedge casts in Finnish Lapland. In: Seppälä, M. \& Eerola, M. (compilers) Nordic symposium on changes in permafrost and periglacial environment : scientific and technical approach, Kevo, Finland, 2-24 August 1999 : programme, participants, abstracts, excursion guide. National Committee for Permafrost Research and Technics, $1 \mathrm{p}$.

Nenonen, K., 1992. Till stratigraphy in southern and western Finland. Bulletin of the Geological Society of Finland 64, 149-160.

Nenonen, K., 1995. Pleistocene stratigraphy and reference sections in southern and western Finland. Geological Survey of Finland: Regional Office for Mid-Finland, $94 \mathrm{p}$.

Nenonen, K., Eriksson, B. \& Grönlund, T., 1991. The till stratigraphy of Ostrobothnia, western Finland, with reference to new Eemian interglacial sites. Striae 34, 6576.

Niemelä, J. \& Jungner, H., 1991. Thermoluminescence dating on late Pleistocene sediments related to till-covered eskers from Ostrobothnia, Finland. Geological Survey of Finland, Special Paper 12, 135-138.

Näslund, J.O., Rodhe, L., Fastook, J.L. \& Holmlund, P., 2003. New ways of studying ice sheet flow directions and glacial erosion by computer modelling - examples from Fennoscandia, Quaternary Science Reviews 22, 245-258.

Penttilä, S., 1963. The deglaciation of the Laanila area, Finnish Lapland. Bulletin de la Commission géologique de Finlande 203, 81 p.

Perttunen, V., 1989. Peräpohjan alueen vulkaniitit. Lapin vulkaniittiprojektin raportti. Summary: Volcanic rocks in the Peräpohja area, northern Finland. A report of the Lapland Volcanite Project. Geological Survey of Finland,
Report of Investigation 92, 40 p.

Perttunen, V., 1991. Kemi, Karunki, Simo and Runkaus. Explanation to the Geological map of Finland 1:100 000, pre-Quaternary rocks, sheets 2541, $2542+2524,2543$ and $2544,80 \mathrm{p}$ (in Finnish with English summary).

Perttunen, V. \& Hanski, E., 2003. Törmäsjärvi and Koivu. Explanation to the Geological map of Finland 1:100 000, pre-Quaternary rocks, sheets 2631 and 2633, 88 p (in Finnish with English summary).

Perttunen, V., Hanski, E., Väänänen, J. \& Silvennoinen, A., 1997. Stratigraphical map of the Peräpohja and Kuusamo areas 1:300 000. Geological Survey of Finland.

Peuraniemi, V., 1982. Geochemistry of till and mode of occurrence of metals in some moraine types in Finland. Geological Survey of Finland, Bulletin 322, 75 p.

Punkari, M., 1984. The relations between glacial dynamics and tills in the eastern part of the Baltic Shield. Striae $20,49-54$.

Punkari, M., 1997. Subglacial processes of the Scandinavian Ice Sheet in Fennoscandia inferred from flow-parallel features and lithostratigraphy. Sedimentary Geology 111, 263-283.

Punkari, M. \& Forsström, L., 1995. Organic remains in Finnish subglacial sediments. Quaternary Research 43, 414-425.

Punning, J.-M. \& Raukas, A., 1983. The age of tills: Problems and methods. In: Evenson, E.B., Schlüchter, Ch. \& Rabassa, J. (eds.) Tills and related deposits. Balkema, Rotterdam, 357-364.

Rainio, H. \& Lahermo, P., 1984. New aspect on the distribution and origin of the so-called dark till. Striae 20, 45-47.

Robertsson, A.-M. \& Garsía Ambrosiani, K., 1988. Late Pleistocene stratigraphy at Boliden, northern Sweden. Boreas 17, 1-14.

Rosberg, J., 1908. Studien über Talbildungen im Finnischen Lappland und dessen Umgebungen. I. Das Tal des Tulomjok. Fennia 24, 1-38.

Saarnisto, M., 2005. Rannansiirtyminen ja maankohoaminen, Itämeren vaiheet ja jokien kehitys. In: Johansson, P. \& Kujansuu, R. (eds.) Pohjois-Suomen maaperä: maaperäkarttojen 1:400 000 selitys. Summary: Quaternary deposits of Northern Finland - explanation to the maps of Quaternary deposits 1:400 000. Geological Survey of Finland, Espoo, 164-171.

Saarnisto, M. \& Salonen, V.-P., 1995. Glacial history of Finland. In: Ehlers, J., Kozarski, S. \& Gibbard, P.L. (eds.) Glacial deposits in North-East Europe. Balkema, Rotterdam, 3-10.

Saarnisto, M., Eriksson, B. \& Hirvas, H., 1999. Tepsankumpu revisited - pollen evidence of stable Eemian climates in Finnish Lapland. Boreas 28, 12-22.

Saarnisto, M. \& Lunkka, J.P., 2004. Climate variability during the last interglacial-glacial cycle in NW Eurasia. In: Battarbee, R. W., Gasse, F. \& Stickley, C. E. (eds.) Past climate variability through Europe and Africa. Develop- 
ments in Paleoenvironmental Research 6, 443-464.

Sarala, P., 1997. Moreenipeitteinen reunaharjanne Korttelivaarassa, Etelä-Lapissa. Summary: A till-covered marginal deposit at Korttelivaara in southern Finnish Lapland. Geologi 49, 55-60.

Sarala, P., 2003. Ribbed-moreenit - jäätikön liikesuunnan poikittaiset indikaattorit. Summary: Ribbed moraines - transverse indicators of the ice flow direction. Geologi 55, 250-253.

Sarala, P., Peuraniemi, V. \& Aario, R., 1998. Glacial geology and till geochemistry in ore exploration in the Tervola area, southern Finnish Lapland. Bulletin of the Geological Society of Finland 70, 19-41.

Sarala, P. \& Rossi, S., 1998. Kupari- ja kultapitoisen hiertovyöhykkeen paikantaminen moreenigeokemiallisin tutkimuksin Peräpohjan liuskealueelta Pohjois-Suomessa. Summary: Discovery of a copper- and gold-bearing shear zone as a result of research into the geochemistry of Peräpohja Schist Belt, northern Finland. Geological Survey of Finland, Report of Investigation 119, 44 p.

Sarala, P. \& Rossi, S., 2000. The application of till geochemistry in exploration in the Rogen moraine area at Petäjävaara, northern Finland. Journal of Geochemical Exploration 68, 87-104.

Siegert, M., Dowdeswell, J., Hald, M. \& Svendsen, J.-I., 2001. Modelling the Eurasian Ice Sheet through a full (Weichselian) glacial cycle. Global and Planetary Change 31, 367-385.

Siivonen, L., 1975. New results on the history and taxonomy of the mountain, forest and domestic reindeer in Northern Europe. Biological Papers of the University of Alaska, Special Report 1, 33-41.

Sutinen, R., 1992. Glacial deposits, their electrical properties and surveying by image interpretation and ground penetrating radar. Geological Survey of Finland, Bulletin 359, $123 \mathrm{p}$.

Svendsen, J.I., Astakhov, V.I., Bolshiyanov, D.Yu., Demidov, I., Dowdeswell, J.A., Gataullin, V., Hjort, C., Hubberten, H.W., Larsen, E., Mangerud, J., Melles, M., Möller, P., Saarnisto, M. \& Siegert, M.J., 1999. Maximum extent of the Eurasian ice sheets in the Barents and Kara Sea region during the Weichselian. Boreas 28, 234-242.

Svendsen, J., Alexanderson, H., Astakhov, V., Demidov, I., Dowdeswell, J., Funder, S., Gataullin, V., Henriksen, M., Hjort, C., Houmark-Nielsen, M., Hubberten, H., Ingolfsson, O., Jakobsson, M., Kjær, K., Larsen, E., Lokrantz, H., Lunkka, J.-P., Lyså, A., Mangerud, J., Matiouchkov, A., Murray, A., Möller, P., Niessen, F., Nikolskaya, O., Polyak, L., Saarnisto, M., Siegert, C., Siegert, M., Spielhagen, R. \& Stein, R., 2004. Late Quaternary ice sheet history of northern Eurasia. Quaternary Science Reviews 23, 1229-1271.

Tanner, V., 1915. Studier öfver kvartärsystemet i Fennoskandians nordliga delar III. Résumé en français. Bulletin de la Commission géologique de Finlande 38, 815 p.

Tanner, V., 1930. Studier öfver kvartärsystemet i Fennoskan- dians nordliga delar IV. Résumé en français. Bulletin de la Commission géologique de Finlande 88, 589 p.

Tanner, V., 1938. Die Oberflächengestaltung Finnlands. Bidrag till kännedom av Finlands natur och folk 86, $762 \mathrm{p}$.

Ukkonen, P., Lunkka, J.-P., Jungner, H. \& Donner, J., 1999. New radiocarbon dates from Finnish mammoths indicating large ice-free areas in Fennoscandia during the Middle Weichselian. Journal of Quaternary Science 14, 711-714.

Voelker, A.H.L., Grootes, P.M., Nadeau, M.-J. \& Sarntheim, M., 2000. Radiocarbon levels in the Iceland Sea from 25-53 kyr and their link to the earth's magnetic field intensity. Radiocarbon 42, 437-452. 
